Article

\title{
Modelling Fine Sediment Dynamics: Towards a Common Erosion Law for Fine Sand, Mud and Mixtures
}

\author{
Baptiste Mengual $^{1, *}$, Pierre Le Hir ${ }^{1}$, Florence Cayocca ${ }^{2}$ and Thierry Garlan ${ }^{3}$ \\ 1 IFREMER/DYNECO/DHYSED, centre de Bretagne, ZI de la pointe du Diable CS 10070, 29280 Plouzané, \\ France; Pierre.Le.Hir@ifremer.fr \\ 2 AAMP (Agence des Aires Marines Protégées), 16 quai de la Douane, 29200 Brest, France; \\ florence.cayocca@aires-marines.fr \\ 3 SHOM/DOPS/HOM/Sédimentologie, 13 rue du Châtellier CS 92803, 29228 Brest, France; \\ thierry.garlan@shom.fr \\ * Correspondence: bapt.mengual@hotmail.fr; Tel.: +33-(0)298-224-491
}

Received: 7 June 2017; Accepted: 18 July 2017; Published: 27 July 2017

\begin{abstract}
This study describes the building of a common erosion law for fine sand and mud, mixed or not, in the case of a typical continental shelf environment, the Bay of Biscay shelf, characterized by slightly energetic conditions and a seabed mainly composed of fine sand and muddy sediments. A 3D realistic hydro-sedimentary model was used to assess the influence of the erosion law setting on sediment dynamics (turbidity, seabed evolution). A pure sand erosion law was applied when the mud fraction in the surficial sediment was lower than a first critical value, and a pure mud erosion law above a second critical value. Both sand and mud erosion laws are formulated similarly, with different parameters (erodibility parameter, critical shear stress and power of the excess shear stress). Several transition trends (linear or exponential) describing variations in these erosion-related parameters between the two critical mud fractions were tested. Suspended sediment concentrations obtained from simulations were compared to measurements taken on the Bay of Biscay shelf with an acoustic profiler over the entire water column. On the one hand, results show that defining an abrupt exponential transition improves model results regarding measurements. On the other hand, they underline the need to define a first critical mud fraction of 10 to $20 \%$, corresponding to a critical clay content of $3-6 \%$, below which pure sand erosion should be prescribed. Both conclusions agree with results of experimental studies reported in the literature mentioning a drastic change in erosion mode above a critical clay content of $2-10 \%$ in the mixture. Results also provide evidence for the importance of considering advection in this kind of validation with in situ observations, which is likely to considerably influence both water column and seabed sediment dynamics.
\end{abstract}

Keywords: sand-mud mixture erosion; numerical modelling; non-cohesive to cohesive transition

\section{Introduction}

The transport of fine sediments can be assumed to mainly occur in suspension. Suspended transport is generally simulated by solving an advection/diffusion equation, assuming that sediment particles have the same velocity as water masses, except the vertical settling component (e.g., [1]). Such an equation involves sink and source terms at the bed boundary, which are deposition and erosion fluxes under conditions defined by the hydraulic forcing and the behaviour and composition of both the suspended and deposited sediments. This means that dealing with fine sediment dynamics, whether or not cohesive, requires the formulation of an erosion law. Such an erosion law should be applicable for fine sands (and even medium sands under strong shear stresses) as well as for mud, and 
naturally for mixtures of sand and mud. Despite these similarities between the suspended transport of fine sand and mud, their erosion processes have generally been investigated separately due to their contrasting behaviours.

An abundant literature is available on cohesive sediments, based on the existence of a critical shear stress for erosion $\left(\tau_{e}\right.$ in $\left.\mathrm{N} \cdot \mathrm{m}^{-2}\right)$ and several empirical relationships between the erosion flux $E$ (in $\mathrm{kg} \cdot \mathrm{m}^{-2} \cdot \mathrm{s}^{-1}$ ) and excess shear stress (i.e., the difference between the actual shear stress $\left(\tau\right.$ in $\mathrm{N} \cdot \mathrm{m}^{-2}$ ) and the critical value $\tau_{e}$, either normalized by the latter or not). The parameters of such an erosion law involve bed characteristics, which may concern electrochemical forces, mineral composition, and organic matter content [2], or pore water characteristics [3]. They also depend on the consolidation state [4], and may be altered by biota effects [5]. Bulk density has often been proposed as a proxy for characterizing the bed, but the plasticity index has also been suggested [6], as well as the undrained cohesion and the sodium adsorption ratio [3].

Literature on sand erosion laws is scarce, partly because of experimental difficulties linked to simultaneous settling and resuspension processes, and partly because sand transport has mainly been considered through the formulation of transport capacity, even in the case of suspension. The need to simultaneously simulate transport of mud and (fine) sand, and their mixture, updates the need for an erosion law for fine sand, often named pick up functions [7]. Pick up functions link the erosion rate with the particle characteristics (size and density) and the shear stress (or, equivalently to the Shields parameter) $[8,9]$. As for cohesive sediment erosion laws, the dependence on the forcing stress is either absolute $(\sim \tau)$ or relative $\left(\sim \tau / \tau_{e}\right)$, involving (or not) a threshold value $\tau_{e}$.

The analogy between erosion formulations for sand and mud can be highlighted, especially considering the Partheniades-Ariathurai law $[10,11]$ for cohesive sediments, the more usual in numerical models. The erosion law can then be written as

$$
E=E_{0} \cdot\left(\tau / \tau_{e}-1\right)^{n}, \text { if } \tau \geq \tau_{e}
$$

where $E_{0}$ is an erodibility parameter in $\mathrm{kg} \cdot \mathrm{m}^{-2} \cdot \mathrm{s}^{-1}$ and $n$ a power function of the sediment composition. In Equation (1), $E_{0}$ and $\tau_{e}$ are functions of the sediment composition and its consolidation state in the case of cohesive sediments, or functions of the particle diameter and density in the case of non-cohesive sediments. Assuming a similar erosion law for the whole range of mixed sediments, the problem becomes the assessment of the critical shear stress for erosion on the one hand, and the erosion factor $E_{0}$ on the other hand, in the full transition range between cohesive and non-cohesive materials. Following Van Ledden et al. [12], the proxy for such a transition could be clay content. An alternative proxy could be mud content (hereafter referred to as $f_{m}$ ), considering that the clay to silt ratio is often uniform in a given study area [13].

Experiments have provided evidence that the resistance to erosion (i.e., critical shear stress $\tau_{e}$ ) increases when mud is added to sand, either because of electrochemical bonds which take effect in binding the sand grains or because a cohesive matrix takes place between and around sand grains (e.g., [6,7,14-17]). Literature on erosion rate for mixed sediments is much less abundant, but a significant decrease (several orders of magnitude) in the erosion rate with mud content is most often reported (e.g., [14,17,18]). For instance, Smith et al. [17] presented laboratory measurements showing a decrease of about two orders of magnitude when the clay fraction in the mixture increased from $0 \%$ to $5-10 \%$, and up to one order of magnitude more when the clay fraction increased from $10 \%$ to $30 \%$.

From the point of view of modelling, Le Hir et al. [1] reviewed the different approaches developed in the last 20 years to manage sand/mud erosion in numerical process-based models. A non-cohesive and a cohesive regime separated by one or two critical mud fractions were commonly introduced and simulated by specific erosion laws. Le Hir et al. [1] and Waeles et al. [19], partly followed by Bi and Toorman [20], used a three-stage erosion law. Below a first critical mud fraction $f_{m c r}$, they considered a non-cohesive regime where the erosion flux of any class of sandy and muddy sediments remains proportional to its respective concentration in the mixture, but is computed according to a pure sand 
erosion law (with a potential modulation of the power applied to the excess shear stress). Starting from a value characteristic of a pure sand bed, critical shear stress in this first regime is either kept constant [1], or linearly increases with the mud fraction $f_{m}[19,20]$. Above a second critical mud fraction $f_{m c r 2}$, these authors defined a cohesive regime: Waeles et al. [19] and Le Hir et al. [1] formulate the erosion law using the relative mud concentration (the concentration of mud in the space between sand grains), considered as more relevant than the mud density in the case of sand/mud mixtures, which was in agreement with observations from Migniot [21] or Dickhudt et al. [22]. Between $f_{m c r 1}$ and $f_{m c r 2 \text {, }}$ they ensured the continuity by prescribing a linear variation of $E_{0}$ and $\tau_{e}$ between non-cohesive and cohesive erosion settings. Carniello et al. [23] used a two-stage erosion law built by Van Ledden [24]: below a critical mud fraction $f_{m c r}$, the erosion factor of the sand fraction is steady and the one for the mud fraction varies slightly according to the factor $1 /\left(1-f_{m}\right)$, while above $f_{m c r}$ the erosion rate is the same for sand and mud fractions and logarithmically decreases according to a power law. Regarding the critical shear stress for erosion, it first slightly increases with $f_{m}$ and then varies linearly to reach the mud shear strength. Dealing only with the critical shear stress, Ahmad et al. [25] proposed an alternative to the Van Ledden [24] expression: without any critical mud fraction, $\tau_{e}$ varies linearly with $f_{m}$ for low values of $f_{m}$ and more strongly for high $f_{m}$ values, using a parameter representing the packing of the sand sediment in the mixture. Generally speaking, the transitional erosion rate between the two regimes is poorly documented.

The aim of this paper is to fit an erosion law for mixed sediments to be applied in environments dominated by fine sediment, such as continental shelves, including our area of interest, the Bay of Biscay continental shelf (hereafter referred to as BoBCS). In these environments that develop outside the coastal fringe where wave impact is higher and where stronger tidal currents may take place, a common sedimentological feature is a mixture of fine sands and mud. In addition, bathymetric gradients are often gentle so that the shear stress gradients are likely to be small: as a consequence, the critical shear stress for erosion of surficial material in equilibrium with such environments is also likely to be low contrasted. Last, suspended sediment concentrations (hereafter referred to as SSC) are rather low in such "deep" coastal waters (at least they are much lower than in shallow waters), and sediment exchanges remain very small: as a consequence, freshly deposited sediment does not consolidate under its own weight, and erosion is so small that the surficial sediment can hardly become over-consolidated. This means that in this context, consolidation appears as a second order process, and that when the surficial sediment is muddy, its shear strength never reaches high values. On the contrary, the surface shear strength is likely to remain close to typical values for fine sand in the order of 0.1-0.2 $\mathrm{Pa}$ (for sands, this range corresponds to the decreasing trend of the Shields parameter with diameter, when the latter is below $0.6 \mathrm{~mm}$ ).

Due to difficulties in measuring erosion fluxes (and not only shear strengths) for sand and mud mixtures, the assessment of the erosion law for fine sediment of the BoBCS is achieved by means of continuous measurements in the field, completed by a realistic hydro-sedimentary model of the specific area for testing the erosion law and its parameterization. In this way, the paper also proposes a methodology for fitting the erosion law in a poorly known natural environment. The paper is organized as follows. Section 2 gives the strategy for assessing the erosion law and describes measurements acquisitions on the one hand, and the modelling framework on the other. The description of the model includes the main features of hydrodynamic and sediment models, and the validation of hydrodynamics computation. Section 3 details the successive steps which led to the building of a new erosion law for sand/mud mixtures. Section 4 presents model results obtained in different erosion settings along with an assessment of their relevance with respect to observations. Section 5 discusses the main results in light of previous studies, followed by a short conclusion in Section 6. 


\section{Strategy and Modelling Background}

\subsection{Strategy for Assessing an Erosion Law, and Its Application to the BoBCS}

Most often erosion laws have been investigated by comparing the critical erosion shear stress and erosion fluxes deduced from the tested law with measurements in a laboratory flume. However, this process has some difficulties. When the sediment is placed or settled in a flume, its behaviour is likely to differ from natural sediment one, especially when cohesive properties begin to develop. In addition, while critical shear stresses can be determined straightforwardly, the erosion flux of the sandy fraction is questionable, mainly because computations generally apply to rough erosion, while measurements often concern a net erosion flux, resulting from this rough erosion and possible simultaneous deposition, which are not easy to characterize. This concern does not apply to the mud fraction.

Here, an alternative methodology is proposed. Selecting an environment where local sediment is representative of the study area, a continuous measurement of suspended sediment concentration and local forcing is used to test the erosion law by simulating observed features by means of modelling. In the likely case of non-negligible horizontal gradients, a full 3D modelling is preferred, as it accounts for all processes, including erosion, deposition and horizontal advection. Deploying field measurements over several months increases the probability of investigating very different forcing conditions, especially if a winter period is selected. The use of an acoustic current profiler enables a simultaneous measurement of local forcing (both current patterns and waves) and resulting resuspension over the whole water column, by analysing the acoustic backscatter. The former observation is used for validating hydrodynamics simulations, while the latter can be compared to predicted SSC according to tested erosion parameters.

\subsection{Measurements Used for Erosion Law Assessment and Model Validation}

As in many continental shelves (e.g., [26,27]), the surficial sediment of the BoBCS is mainly composed of fine sand $(\sim 200 \mu \mathrm{m})$ and mud, since water depths exceed the depth of wave-induced frequent reworking, typically about $20-30 \mathrm{~m}$, for the wave regime of the Bay of Biscay. The erosion law for fine sediment mixtures has been fitted by selecting measurements in a rather representative environment of the shelf, both in terms of sediment cover, hydrodynamic forcing and near bottom turbidity. A station located near the coast of southern Brittany, close to Le Croisic (hereafter referred to as $L C$ station, Figure 1) meets these criteria: the local water depth is $23 \mathrm{~m}$ on average and the exposure to waves is attenuated by a rocky bank localised in the southwest nearby. Despite a tidal range of 4-5 m, tidal currents remain low, and flow is likely to be controlled by wind-induced currents [28]. The seabed is constituted by muddy sands $\left(d_{10}\right.$ of $7.5 \mu \mathrm{m}, d_{50}$ of $163 \mu \mathrm{m}, 5.1 \%$ clay $(\%<4 \mu \mathrm{m})$ and $25 \%$ mud $(\%<63 \mu \mathrm{m})$ contents), and exhibits some gradients around the station, with muddy facies to the north, and more sandy ones to the south (Figure 1).

For measurements, a mooring line was deployed over the whole water column for two months between 25 November 2007 and 31 January 2008. This period corresponded to typical winter hydrodynamic and meteorological conditions: mainly south-westerly winds, high rates of river discharge (e.g., Loire river: average flow rate of $1161 \mathrm{~m}^{3} \cdot \mathrm{s}^{-1}$, and maximum flow rate of $2240 \mathrm{~m}^{3} \cdot \mathrm{s}^{-1}$ ), and rather large swells $\left(H_{s}\right.$ (significant wave height) peaks $>3 \mathrm{~m}, T_{p}$ (peak period) $10-18 \mathrm{~s}$ ).

Several instruments were placed along the mooring line. A MS5-Hydrolab sensor (OTT Hydromet, Kempten, Germany) providing temperature and salinity measurements (at $60 \mathrm{~min}$ intervals) was fixed $1.50 \mathrm{~m}$ below the sea surface. An upward looking acoustic Doppler profiler (Acoustic Wave And Current profiler, $1000 \mathrm{KHz}$, Nortek AS, Vangkroken 2, Norway; hereafter referred to as AWAC) was fixed on a structure placed near the seabed to record the backscattered acoustic intensity (at $30 \mathrm{~min}$ intervals), the intensity and direction of the currents ( $1 \mathrm{~min}$ of time-integrated data at $30 \mathrm{~min}$ intervals), water elevation (at $30 \mathrm{~min}$ intervals), as well as wave height, period, and direction (at $60 \mathrm{~min}$ intervals). The return echo was sampled over the entire water column with $25 \mathrm{~cm}$-thick cells. In this configuration, 
the first sampling cell of the $A W A C$ profiler was located $1.67 \mathrm{~m}$ above the seabed (including the frame height and the AWAC blank distance). At the same elevation, a turbidity sensor (WETlabs; Sea-Bird Scientific, Bellevue, Washington, DC, USA) provided hourly measurements for calibration. This turbidity signal was further transformed to SSC in $\mathrm{mg} \cdot \mathrm{L}^{-1}$ using water samples. The backscatter index (BI) from the AWAC profiler was evaluated from the sonar equation [29], following the procedure described by Tessier et al. [30], in particular by considering the geometrical attenuation for spherical spreading, the signal attenuation induced by the water, and the geometric correction linked to the expansion of the backscattering volume with increasing distance from the source. Given that SSC derived from the turbidity sensor did not exceed $100 \mathrm{mg} \cdot \mathrm{L}^{-1}$, the signal attenuation caused by the particles was disregarded when estimating backscatter [30]. Then, an empirical relationship was established between the BI of first AWAC cell and SSC measurements of turbidity sensor, following Tessier et al. [30]:

$$
\operatorname{10log}_{10}(S S C)=c_{1} \cdot B I+c_{2}
$$

We finally obtained a determination coefficient $R^{2}$ of 0.78 with $c_{1}=0.42794$ and $c_{2}=32.8907$. Changes in SSC concentrations in the water column could thus be quantified (Section 4).

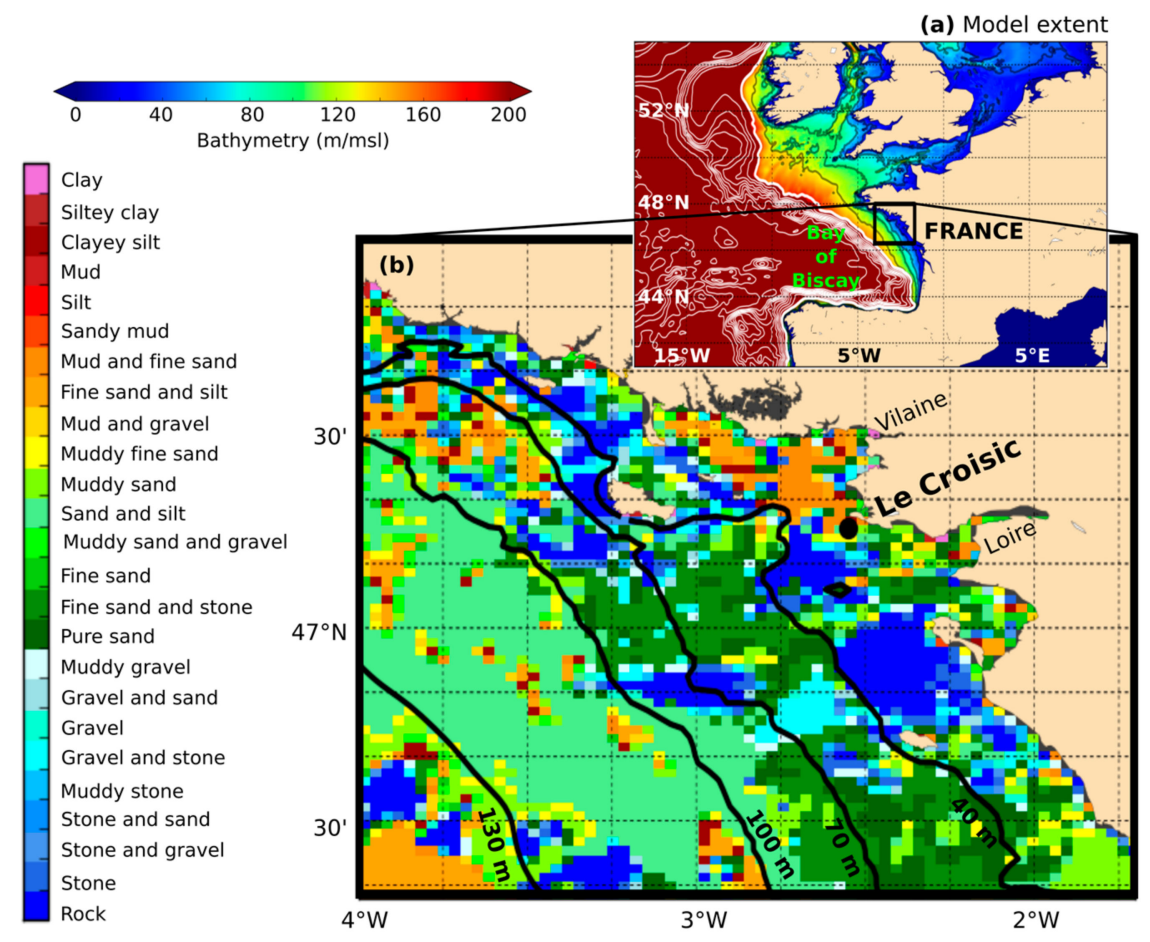

Figure 1. Geographic extent of the 3D model configuration with its bathymetry (in meters with respect to mean sea level) (a). Initial condition for the seabed compartment (at the resolution of the model) (b), over the zone surrounding Le Croisic station (indicated by a black dot). In (a), the thickest white line represents the $180 \mathrm{~m}$ isobath, which can be considered as the external boundary of the continental shelf. In both subplots, black lines refer to the 40-m, 70-m, 100-m, and 130-m isobaths over the shelf.

\subsection{Hydrodynamics Models (Waves, Currents)}

\subsubsection{Brief Description}

Current patterns and advection of suspended sediments were computed with the three-dimensional MARS3D model (3D hydrodynamic Model for Applications at Regional Scale, IFREMER), described in detail by Lazure and Dumas [31]. This code solves the primitive equations under classical Boussinesq and hydrostatic pressure assumptions. The model configuration spreads from $40^{\circ} 58^{\prime} 39^{\prime \prime} \mathrm{N}$ to $55^{\circ} \mathrm{N}$ in latitude, and from $18^{\circ} 2^{\prime} 1^{\prime \prime} \mathrm{W}$ to $9^{\circ} 30^{\prime} \mathrm{E}$ in longitude (Figure 1) with a 
uniform horizontal resolution of $2500 \mathrm{~m}$ ( $822 \times 624$ horizontal grid points). The vertical discretization is based on 40 generalized sigma layers. For water depths lower than $15 \mathrm{~m}$, sigma levels are uniformly distributed through the water column. Above this depth, a resolution increase is prescribed in the lower and upper parts of the water column, following the formulation of Song and Haidvogel [32]. For instance, this setting leads to a bottom cell of $40 \mathrm{~cm}$ for a total water depth of $25 \mathrm{~m}$. The numerical scheme uses a mode splitting technique with an iterative and semi-implicit method which allows simultaneous calculation of internal and external modes at the same time step. In our case, the time step is fixed at $150 \mathrm{~s}$. Vertical viscosity and diffusivity for temperature, salinity and momentum were obtained using the $k-\varepsilon$ turbulence closure of Rodi [33]. Simulations were performed with the realistic forcings detailed in Table 1.

Table 1. Realistic forcings used in 3D simulations.

\begin{tabular}{lc}
\multicolumn{1}{c}{ Forcing } & Source \\
\hline $\begin{array}{l}\text { Initial \& boundary conditions (3D velocities, } \\
\text { temperature, salinity) }\end{array}$ & GLORYS global ocean reanalysis [34] \\
\hline $\begin{array}{l}\text { Wave (Significant height, peak period, bottom } \\
\text { excursion and orbital velocities) }\end{array}$ & WaveWatch III hindcast [35] \\
\hline $\begin{array}{l}\text { Meteorological conditions (Atmospheric pressure, } \\
\text { wind, temperature, relative humidity, cloud cover) }\end{array}$ & ARPEGE model [36] \\
\hline Tide (14 components) & FES2004 solution [37] \\
\hline River discharge (flow and SSC) & Daily runoff data (French freshwater office) \\
\hline
\end{tabular}

Regarding wave forcing, a wave hindcast database built with the WaveWatchIII (WWIII) model (realistic and validated configuration of Boudière et al. [35]) enabled the computation of bottom wave-induced shear stresses $\left(\tau_{w}\right.$ in $\left.\mathrm{N} \cdot \mathrm{m}^{-2}\right)$. The wave-induced shear stress was computed according to the formulation of Jonsson [38], with a wave-induced friction factor determined following Soulsby et al. [39]. Then, the total bottom shear stress $\tau$ was computed from the estimated $\tau_{w}$ and from the current-induced shear stress $\left(\tau_{c}\right.$ in $\left.\mathrm{N} \cdot \mathrm{m}^{-2}\right)$ provided by the hydrodynamic model, according to the formulation of Soulsby [40], i.e., accounting for a non-linear interaction between waves and currents. Both wave and current shear stresses were computed by considering a skin roughness length $z_{0}$ linked to a $200 \mu \mathrm{m}$ sand, representative of the sandy facies widely encountered on the BoBCS $\left(z_{0}=k_{s} / 30=2 \times 10^{-5} \mathrm{~m}\right.$ with $k_{s}$ the Nikuradse roughness coefficient).

\subsubsection{Hydrodynamic Validation of the Model}

Figure 2 shows model validation regarding hydrodynamics at the $L C$ station from 1 December 2007 to 18 January 2008 in terms of significant wave height $\left(H_{S}\right)$, surface temperature and salinity ( $T_{S}$ and $S_{S}$, respectively), and current intensity and direction $\left(\operatorname{Vel}_{I N T}\right.$ and $V e l_{D I R}$, respectively).

Measurements highlight typical late autumn/winter energetic conditions. Average $H_{S}$ were around $1.5 \mathrm{~m}$ and occasionally exceeded $4 \mathrm{~m}$ in stormy conditions. Peak periods (not illustrated here) ranged from 8 to $18 \mathrm{~s}$ (around $10 \mathrm{~s}$ on average). Even during "calm" periods, $H_{S}$ values are generally no lower than $0.8 \mathrm{~m}$. Figure 2a illustrates the ability of the model of Boudière et al. [35] to describe $H_{S}$ over the period, with a root mean square error (RMSE) of $0.24 \mathrm{~cm}$ and a $R^{2}$ of 0.95 . Measured and modelled $T_{S}$ and $S_{S}$ are illustrated in Figure $2 b, c$ respectively, and demonstrate the correct response of the model with respect to observations with $R M S E / R^{2}$ values of $0.5^{\circ} \mathrm{C} / 0.86$ for $T_{S}$ and 2 PSU $/ 0.7$ for $S_{S}$. The weaker correlation obtained for $S_{S}$ is mainly due to model underestimation around 2 January 2008 (i.e., about 5 PSU). It should be underlined that the model accurately reproduces the abrupt change (decrease) in surface temperature and salinity on 11 December 2007, linked to the veering of the Loire river plume caused by easterly winds. This plume advection led to stratification which in turn influenced the vertical profiles of currents in terms of direction and intensity (Figure 2e,g, 
respectively), which are well represented by the model. More generally, the model provides an appropriate response regarding the direction and intensity of the current (Figure 2d,f) over the entire water column throughout the period. For instance, measured bottom current velocities $\left(0.11 \mathrm{~m} \cdot \mathrm{s}^{-1}\right.$ on average, max of $0.44 \mathrm{~m} \cdot \mathrm{s}^{-1}$ ) are correctly reproduced by the model with a RMSE of $0.05 \mathrm{~m} \cdot \mathrm{s}^{-1}$.

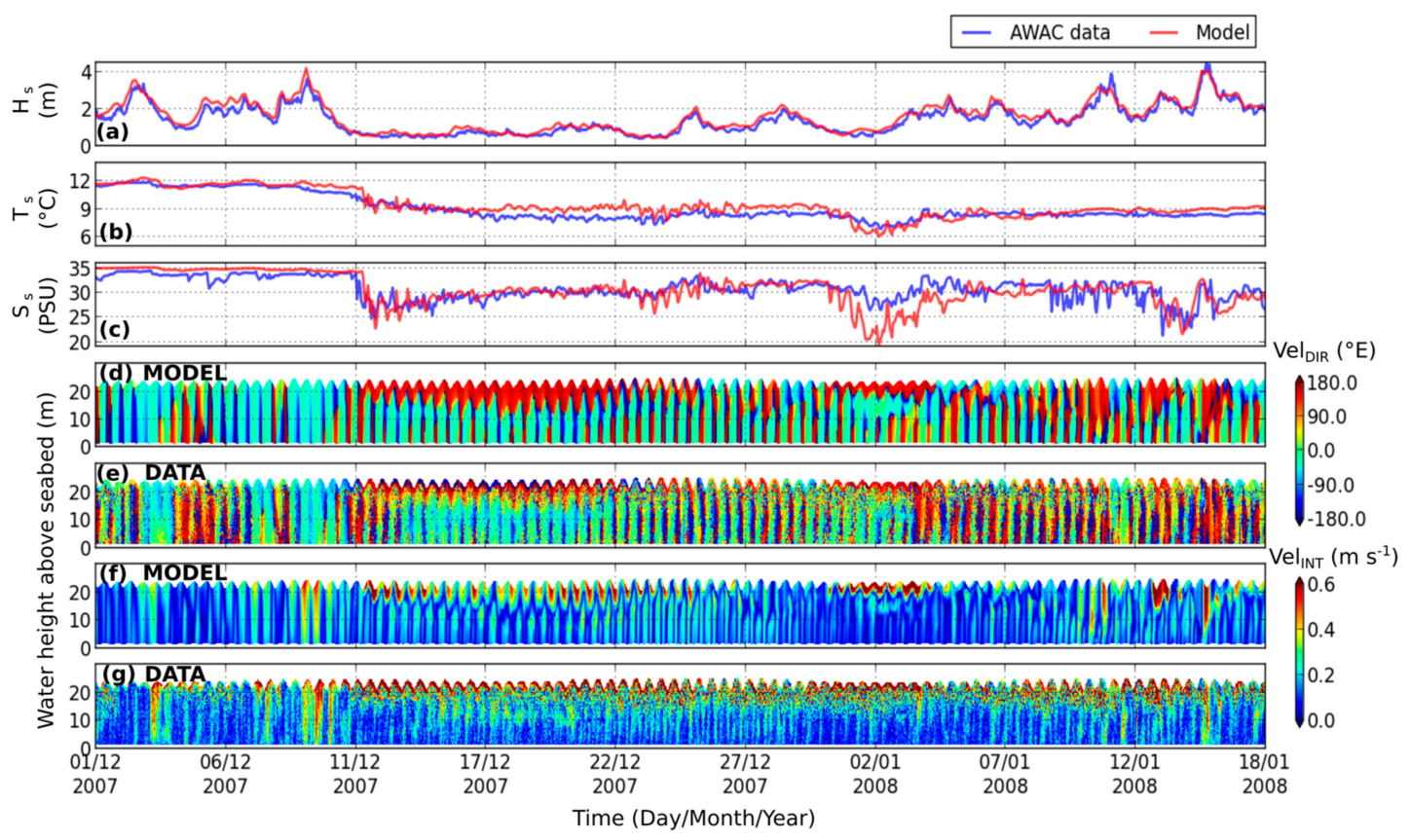

Figure 2. Validation of the hydrodynamic model over most of the simulated period at $L C$ station. Model results are compared with $A W A C$ measurements in terms of (a) significant wave height, (b) surface temperature, (c) surface salinity, current direction $((\mathbf{d}, \mathbf{e})$, respectively), and current intensity $((\mathbf{f}, \mathbf{g})$, respectively).

\subsection{Sediment Transport Model}

The sediment model used in the present 3D modelling system is described in Le Hir et al. [1]. The model makes it possible to simulate the transport and changes in all kinds of sediment mixtures under the action of hydrodynamic forcing, including that of waves and currents. According to the model concept, the consolidation state of the bottom sediment is linked to the relative mud concentration, i.e., the concentration of mud in the space between the sand grains $\left(C_{\text {rel mud }}\right)$. Given that the surficial sediment in our study area is weakly consolidated (erosion actually occurs in surficial layers only, typically a few $\mathrm{mm}$ or $\mathrm{cm}$ thick) and mainly composed of fine sand, consolidation was disregarded and $C_{\text {rel mud }}$ was set at a constant value of $550 \mathrm{~kg} \cdot \mathrm{m}^{-3}$ (representative of pre-consolidated sediment according to Grasso et al. [41]). In addition, bed load was not taken into account in the present application, assuming that surficial sediment in our study area is mainly composed of mixtures of mud and fine sand. In our case, three sediment classes (for which the mass concentrations are the model state variables) are considered: a fine sand (S1), a non-cohesive material with a representative size of $200 \mu \mathrm{m}$, and two muddy classes (M1 and M2), which can be distinguished by their settling velocity, in order to be able to schematically represent the vertical dispersion of cohesive material over the shelf. The sediment dynamics was computed with an advection/dispersion equation for each sediment class, representing transport in the water column, as well as exchanges at the water/sediment interface linked to erosion and deposition processes. Consequently, the concentrations of suspended sediment, the related horizontal and vertical fluxes, and the corresponding changes in the seabed (composition and thickness) are simulated. This section details the way of managing sediment deposition, seabed initialization, and technical aspects linked to vertical discretization within the seabed compartment. 
The erosion law establishment and the numerical modelling experiment aiming to fit an optimal setting will be addressed independently in Section 3.

\subsubsection{Managing Sediment Deposition}

The deposition flux $D_{i}$ for each sediment class $i$ is computed according to the Krone law:

$$
D_{i}=W_{s, i} \cdot S S C_{i} \cdot\left(1-\frac{\tau}{\tau_{d, i}}\right)
$$

In Equation (3), $\tau$ is the total bottom shear stress (waves and currents; see Section 2.3.1), $W_{s, i}$ is the settling velocity, $S S C_{i}$ is the suspended sediment concentration, and $\tau_{d, i}$ is the critical shear stress for deposition. In the present study, the latter was set to a very high value $\left(1000 \mathrm{~N} \cdot \mathrm{m}^{-2}\right)$ so it is ineffective: considering that consolidation processes are negligible near the interface and that, as a result, the critical shear stress for erosion remains low (Section 3), deposited sediments can be quickly resuspended in the water column if the hydrodynamic conditions are sufficiently intense, which replaces the role played by the term between parentheses in Equation (3) [1].

The settling velocity of non-cohesive sediment $\left(W_{s, S 1}\right)$ is computed according to the formulation of Soulsby [40]. The one related to the mud $M 1\left(W_{s, M 1}\right)$ is assumed to vary as a function of its concentration in the water column $\left(S S C_{M 1}\right)$ and the ambient turbulence according to the formulation of Van Leussen [42]:

$$
W_{s, M 1}=\max \left\{W_{s, \min } ; \min \left\{W_{s, \max } ; k \cdot S S C_{M 1}^{m} \cdot\left(\frac{1+a \cdot G}{1+b \cdot G^{2}}\right)\right\}\right\}, \text { with } G=\sqrt{\frac{\varepsilon}{v}}
$$

where $k, m, a$ and $b$ are empirical constants, $G$ is the absolute velocity gradient, $\varepsilon$ is the turbulent dissipation rate, and $v$ is the water viscosity. For $a$ and $b$, respective values of 0.3 and 0.09 , set by Van Leussen [42] from experiments, were used. In agreement with the settling velocity setting used by Tessier et al. [43] in a modelling study of turbidity over the southern Brittany continental shelf and recent experiments by Verney et al. [44] in similar environments in the Gulf of Lions, $k$ and $m$ were respectively set to 0.005 and 0.7 . Following Tessier et al. [43], $W_{s, M 1}$ is limited by minimum $\left(W_{s, \text { min }}\right)$ and maximum $\left(W_{s, \max }\right)$ values, respectively set to $0.1 \mathrm{~mm} \cdot \mathrm{s}^{-1}$ and $4 \mathrm{~mm} \cdot \mathrm{s}^{-1}$, the latter being reached for SSC $\geq 700 \mathrm{mg} \cdot \mathrm{L}^{-1}$ (thus ignoring the hindered settling process which actually does not occur in the range of SSC over the shelf). Lastly, the mud M2 linked to ambient turbidity in the water column is assumed to have a constant very low settling velocity set to $2.5 \times 10^{-6} \mathrm{~m} \cdot \mathrm{s}^{-1}$.

After resolving the sediment transport equation, the actual deposition on the bottom can be computed. In agreement with Le Hir et al. [1], sand and mud particles are deposited successively, by filling the pores or by creating new layers. A volume concentration of well-sorted sediment $\left(C_{\text {vol sort }}=0.58\right)$ was attributed to sediment when only one class of non-cohesive sediment is present. However, the bed concentration can reach a higher value if several classes are mixed $\left(C_{\text {vol mix }}=0.67\right)$. These typical volume concentrations [45] led to mass concentrations assuming a fixed sediment density ps $\left(2600 \mathrm{~kg} \cdot \mathrm{m}^{-3}\right)$ for all classes. In the case of simultaneous deposition of sand and mud, the sand is first deposited at a concentration which depends on surficial sediment composition: in the case of mixed sediment, the sand is first mixed with the initial mixture until $C_{\text {mix }}\left(=C_{\text {vol mix }} \cdot \rho_{s}=1742 \mathrm{~kg} \cdot \mathrm{m}^{-3}\right)$ is reached. The remaining sand is deposited with the concentration $C_{\text {sort }}\left(=C_{\text {vol sort }} \cdot \rho_{s}=1508 \mathrm{~kg} \cdot \mathrm{m}^{-3}\right)$, from which an increase in the thickness of the layer can be deduced. The same kind of deposition occurs when the surficial sediment is only comprised of sand. In addition, the thickness of any layer is limited to $d z_{\text {sed, max }}$, a numerical parameter of the model. Any deposition of excess sand leads to the creation of a new layer (see Section 2.4.2). Next, mud is deposited: it progressively fills up pores between the sand grains until either $C_{m i x}$ or $C_{\text {rel mud }}$ is reached. Considering these criteria, mud is mixed within the initial and new deposits starting from the water/sediment interface. If any excess mud remains after the mixing step, it is added to the upper sediment layer, contributing to its thickening. 


\subsubsection{Sediment Discretization within the Seabed}

In the model, an initial sediment height $\left(h_{\text {sed, ini }}\right)$ is introduced, and the seabed is vertically discretized in a given number of layers of equivalent thicknesses $\left(d z_{s e d, i n i}\right)$. An optimal vertical discretization of the sediment was assessed by Mengual [46]. By means of sensitivity analyses, it was shown that beyond a $1 / 3 \mathrm{~mm}$ resolution within the seabed compartment (i.e., thickness of each layer $\left.d z_{s e d, \text { ini }}\right)$, the SSC response of the model in the water column did not change anymore. According to the conclusions drawn from this sensitivity analysis, the initial sediment thickness $h_{\text {sed, ini }}$ was set at $0.03 \mathrm{~m}$, corresponding to 90 sediment layers of thickness $d z_{\text {sed, ini }}(1 / 3 \mathrm{~mm})$.

As previously mentioned in Section 2.4.1, a new layer is created when the actual deposition leads to a thickness of the surficial sediment layer higher than a maximum value $d z_{\text {sed, } \max }$, corresponding to a parameter of the model. Nevertheless, a maximum number of layers in the seabed compartment $\left(N_{\max }\right)$ needs to be defined in order to make computational costs acceptable. While $N_{\max }$ is reached, a fusion of the two sediment layers located at the base of the sedimentary column occurs. By this way, the creation of new deposited layers becomes once again possible. The parameters $d z_{\text {sed, max }}$ and $N_{\max }$ control changes of the "sediment vertical discretization" during the simulation, and are likely to influence the sediment dynamics. To prevent any variations in the SSC response of the model linked to changes in the seabed vertical resolution, the maximum thickness of sediment layers, $d z_{\text {sed, } \max }$, was set at the same value than the initial one $d z_{\text {sed, ini }}$.

This seabed management constitutes a compromise between the likely maximum erosion depth in most of the shelf and the possibility of new layers being deposited in other places.

\subsubsection{Sediment Facies Initialization for the Application to the BoBCS}

The seabed was initialized using the distribution of the three sediment classes according to existing surficial sediment maps (e.g., [47]) and for the sand and mud fractions, new sediment samples taken in the BoBCS (Figure 1). No sediment initialization was undertaken in areas indicated as rocky on sediment maps. The mud $M 2$, characterized by a very low settling velocity, is linked to river inputs and was also uniformly initialized $\left(20 \mathrm{~kg} \cdot \mathrm{m}^{-3}\right)$ on the seabed over the entire shelf. This particle class enables the representation of a non-negligible part of the ambient turbidity of a few $\mathrm{mg} \cdot \mathrm{L}^{-1}$ near the coast.

Given the sand fraction $f_{s}$ of the mixed sediment, a relationship could be derived between $C_{\text {rel mud }}$ (relative mud concentration set at a constant value of $550 \mathrm{~kg} \cdot \mathrm{m}^{-3}$ ) and the bulk sediment density $\left(C_{\text {bulk }}\right)$. The latter can be written as:

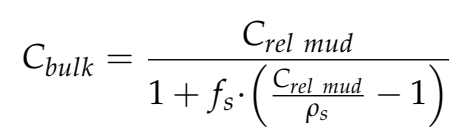

For large sand fraction (above 90\%), the given relative concentration of $550 \mathrm{~kg} \cdot \mathrm{m}^{-3}$ becomes unlikely, so that $C_{\text {bulk }}$ is maximised by $C_{\text {max }}$, which corresponds to a dense sediment $\left(C_{\text {sort }}\right.$ or $C_{\text {mix }}$ depending on the properties of the sediment mixture, i.e., well-sorted or mixed sediments). This formulation could be validated by comparing with recent data in two sectors of the BoBCS [48]: bulk densities of $1540 \mathrm{~kg} \cdot \mathrm{m}^{-3}$ and $1380 \mathrm{~kg} \cdot \mathrm{m}^{-3}$ were obtained for $85 \%$ and $75 \%$ of sand, respectively, while the application of Equation (5) with sand fractions $f_{s}$ of 0.85 and 0.75 led to $C_{b u l k}$ values of $1668 \mathrm{~kg} \cdot \mathrm{m}^{-3}$ and $1346 \mathrm{~kg} \cdot \mathrm{m}^{-3}$ in fair agreement. Sediment concentrations linked to each particle class were then deduced according to their respective fraction.

Lastly, the sediment distribution has been prescribed uniformly along the vertical dimension (i.e., in each layer of the seabed compartment) in the absence of 3D data on grain size distributions. 


\section{Erosion Law Setting: Building and Numerical Experiment}

\subsection{General Formulation}

As previously evoked in the introduction, the Partheniades-Ariathurai law [10,11], the most commonly used for cohesive sediments, can also represent the pick up process of fine sands. Such an erosion law is then assumed whatever the sediment composition. In the present study, the erosion flux $E$ is thus expressed following Equation (1). A simultaneous erosion of sandy and muddy fractions is assumed, according to their respective concentration in the mixture.

This erosion law involves three parameters, $E_{0}$ (erodibility parameter, $\left.\mathrm{kg} \cdot \mathrm{m}^{-2} \cdot \mathrm{s}^{-1}\right), \tau_{e}$ (critical shear stress, $\mathrm{N} \cdot \mathrm{m}^{-2}$ ), and $n$ (hereafter referred to as "erosion-related parameters"), which are set at different values depending on the mud content $f_{m}(<63 \mu \mathrm{m})$ of the surficial sediment. The concept of critical mud fraction is retained, with the definition of a first critical fraction $f_{m c r}$ below which a non-cohesive behaviour is prescribed, and of a second one, $f_{m c r}$, above which the sediment is assumed to behave as pure mud. Two sets of erosion-related parameters will be defined below and above these mud fractions (see Sections 3.2 and 3.3 for sand and mud, respectively). As already mentioned in Section 1, a transition in erosion-related parameters has to be prescribed between $f_{m c r 1}$ and $f_{m c r 2}$ (between pure sand and pure mud parameters) to manage the erosion of "transitional" sand/mud mixtures. Such a transition is investigated in Section 3.4.

\subsection{Pure Sand Erosion}

Below the first critical mud fraction $f_{m c r 1}$, the non-cohesive erosion regime is prescribed by defining a first set of erosion-related parameters linked to pure sand erosion in Equation (1): $E_{0, s a n d}$, $\tau_{e, \text { sand }}$, and $n_{\text {sand }}$. Le Hir et al. [1] suggested to compute $f_{m c r 1}$ as a function of the sand mean diameter $D\left(f_{m c r 1}=\alpha_{0} \times D\right.$ with $\left.\alpha_{0}=10^{3} \mathrm{~m}^{-1}\right)$, leading to a value of $20 \%$ considering the fine sand $S 1$ of $200 \mu \mathrm{m}$ (considered as a reference value hereafter). However, the model erosion dynamics is likely to significantly vary while the surficial mud fraction $f_{m}$ is close to $f_{m c r}$. Such a sensitivity is addressed in Section 4.2.

In Equation (1), parameters linked to pure sand erosion $E_{0, \text { sand }}, \tau_{e, s a n d}$, and $n_{\text {sand }}$ were deduced from numerical simulations and empirical formulations. According to Van Rijn [49] and many other numerical models (e.g., $[23,24]$ ), the best fit for $n_{\text {sand }}$ is 1.5 . The critical shear stress $\tau_{e \text {,sand }}$ was determined from the Shields critical mobility parameter computed according to the formulation of Soulsby [40], leading to a value of $0.15 \mathrm{~N} \cdot \mathrm{m}^{-2}$ for a sand of $200 \mu \mathrm{m}$.

Considering that equilibrium conditions are usually met for non-cohesive sediment transport, and that such an equilibrium requires compensation between the erosion rate and the deposition flux, many authors formulate the erosion rate (or pick up function) as:

$$
E=W_{s} \cdot C_{r e f}
$$

where $W_{s}$ is the settling velocity and $C_{r e f}$ is a reference concentration which characterizes the equilibrium. The description of $C_{r e f}$ is generally associated with the reference height, $h_{r e f}$, the distance from the bed where the concentration is considered. In point of fact, this location has to be the one where the equilibrium between deposition and erosion is considered, with respective values that largely depend on the reference height, because of large concentration gradients near the bed. From the point of view of sediment modelling, this means that the deposition flux at the base of the water column has to be expressed at the exact location where the erosion flux is considered, that is, at the reference height where the equilibrium concentration is given. Van Rijn [49] used the concept of equilibrium concentration as a boundary condition of the computation of suspended sediment profile and fitted the expression:

$$
C_{r e f}=0.015 \rho_{s} D /\left(h_{r e f} \cdot D_{*}^{0.3}\right) \cdot\left(\tau / \tau_{e}-1\right)^{1.5}
$$


where $D_{*}$ is the non-dimensional median sand diameter $\left(D_{*}=D\left(\sigma g / v^{2}\right)^{1 / 3}\right.$ with $\sigma=\left(\rho_{s} / \rho-1\right)$, $\rho$ being the water density, $g$ the gravitational acceleration, and $v$ the water viscosity). Using the $C_{r e f}$ formulation of Van Rijn [49] in Equation (6) enables us to express the $E_{0, \text { sand }}$ constant in the "Partheniades" form of the erosion law as:

$$
E_{0, \text { sand }}=\frac{0.015 \rho_{s} D W_{s, S 1}}{h_{r e f} D_{*}^{0.3}}
$$

For $D=200 \mu \mathrm{m}(S 1), h_{r e f}=0.02 \mathrm{~m}$, and $W_{s, S 1}=2.5 \mathrm{~cm} \cdot \mathrm{s}^{-1}$, Equation (8) leads to $E_{0, \text { sand }}=5.94 \times$ $10^{-3} \mathrm{~kg} \cdot \mathrm{m}^{-2} \cdot \mathrm{s}^{-1}$. The relevance of this $E_{0, \text { sand }}$ value was assessed by simulating an equilibrium state under a steady current and by comparing the depth-integrated horizontal sediment flux with some standard transport capacity formulations. Using a 1DV version of the code, several computations of fine sand resuspension were performed under different flow intensities $\left(\operatorname{Vel}_{I N T}\right)$, and once the equilibrium was reached $($ deposition $=$ resuspension $)$ the total transport $\left(Q_{\text {sand }}\right)$ was computed as:

$$
Q_{\text {sand }}=\frac{1}{\rho_{s}} \int_{k=1}^{n} \operatorname{Vel}_{I N T}(k) \cdot S S C_{S 1}(k) \cdot d z(k)
$$

where $d z(k)$ refers to the thickness of the cell $k$ (in $\mathrm{m}$ ) in the water column (discretized in $n$ layers along the vertical dimension) and $S S C_{S 1}(k)$ to the suspended sediment concentration of sand (S1) in the cell $k$. Sand transport rates $Q_{\text {sand }}$ were then compared to the rates deduced from the formulations of Van Rijn [50], Engelund and Hansen [51], and Yang [52] for similar flow velocities (hereafter $Q_{\text {sand,VR1984, }}$

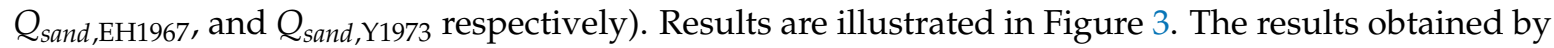
Dufois and Le Hir [53], who also used an advection/diffusion model to predict sand transport rates for a wide range of current conditions and numerous sand diameters, have been added in Figure 3 $\left(Q_{\text {sand,DLH2015 }}\right)$. Figure 3 shows that the sand transport rates obtained from our computations are in a consistent range regarding those obtained with other formulations or studies cited in the literature, demonstrating the suitability of our $E_{0, \text { sand }}$ parameter.

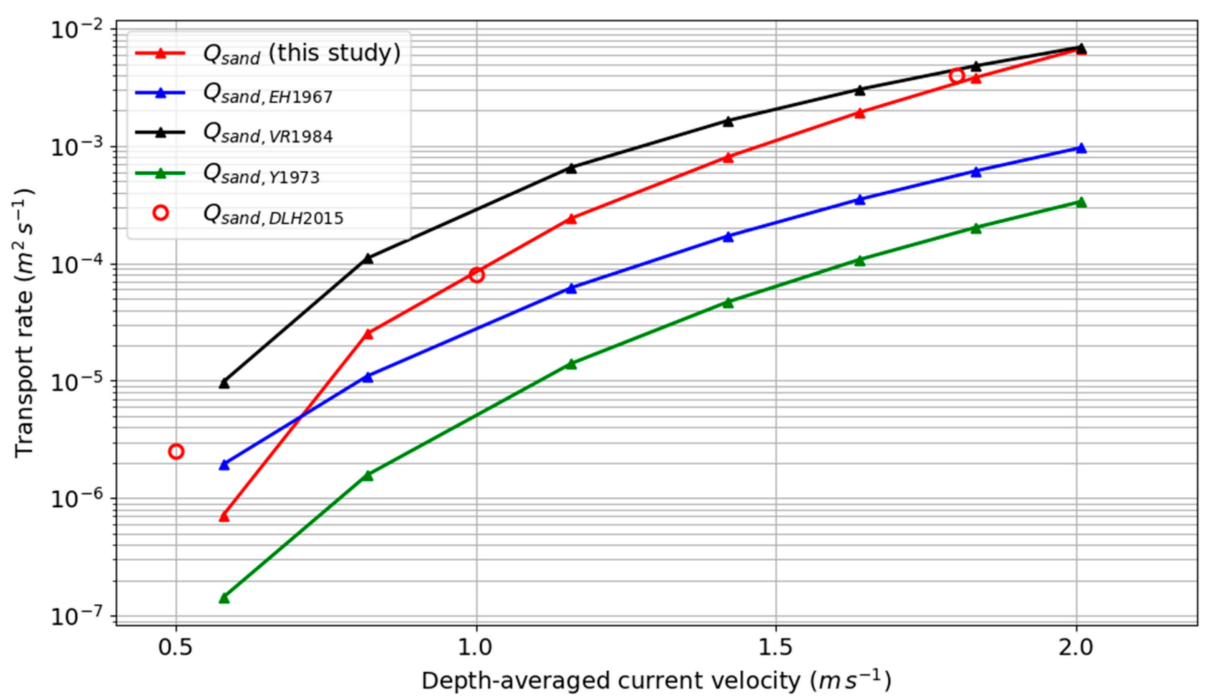

Figure 3. Sand ( $200 \mu \mathrm{m}$ diameter) transport rates computed with a 1DV model using the pure sand erosion law, and obtained for different flow intensities (solid red curve). For identical flow intensities and sand diameter, sand transport rates deduced from empirical formulations of Van Rijn [50] (black curve), Engelund and Hansen [51] (blue curve), and Yang [52] (green curve) are illustrated. Empty red circles refer to the modelling results of Dufois and Le Hir [53] representing transport rates of a $200 \mu \mathrm{m}$ sand under different flow intensities from an advection/diffusion model. 
The erosion-related parameters $E_{0, \text { sand }}, \tau_{e, \text { sand }}$, and $n_{\text {sand }}$ for fine sand are summarized in Table 2 and constitute reference parameters characterizing pure sand erosion.

Table 2. Erosion parameters for pure sand and pure mud sediment.

\begin{tabular}{|c|c|c|c|}
\hline Erosion Regime & $E_{0}\left(\mathrm{~kg} \cdot \mathrm{m}^{-2} \cdot \mathrm{s}^{-1}\right)$ & $\tau_{e}\left(\mathrm{~N} \cdot \mathrm{m}^{-2}\right)$ & $n$ \\
\hline $\begin{array}{l}\text { Non-cohesive (pure sand) } \\
\text { Cohesive (pure mud) }\end{array}$ & $\begin{array}{c}E_{0, \text { sand }}=5.94 \times 10^{-3} \\
E_{0, \text { mud }}=10^{-5}\end{array}$ & $\begin{array}{c}\tau_{e, \text { sand }}=0.15 \\
\tau_{e, \text { mud }}=0.1\end{array}$ & $\begin{array}{c}n_{\text {sand }}=1.5 \\
n_{m u d}=1\end{array}$ \\
\hline
\end{tabular}

\subsection{Pure Mud Erosion}

Above the second critical mud fraction $f_{m c r 2}$ (reference value of $70 \%$ according to the default value used by Le Hir et al. [1]), the cohesive erosion regime is prescribed by defining a second set of erosion-related parameters linked to pure mud erosion in Equation (1): $E_{0, m u d}, \tau_{e, m u d}$, and $n_{m u d}$.

As frequently specified in the Partheniades-Ariathurai formulation, the $n_{m u d}$ exponent was set to 1. Given the lack of established formulation of the erosion factor for pure mud, experimental approaches are often used to calibrate it for specific materials, preferably in situ when possible. For this purpose, a specific device had been designed: the "erodimeter" is described in Le Hir et al. [7]. It consists of a small recirculating flume where a unidirectional flow is increased step by step and interacts with a sediment sample carefully placed at the bottom after transfer from a cylindrical core. When measurements are made on board an oceanographic vessel, the test can be considered as quasi in situ. On the BoBCS, erosion tests had been conducted on board the Thalassa N/O: a few of them were performed on muddy sediment samples (mud content higher than $80 \%$ ). Figure 4 illustrates the critical shear stress for erosion $\tau_{e, m u d}$, estimated to be $0.1 \mathrm{~N} \cdot \mathrm{m}^{-2}$, suggesting a barely-consolidated easily erodible sediment.

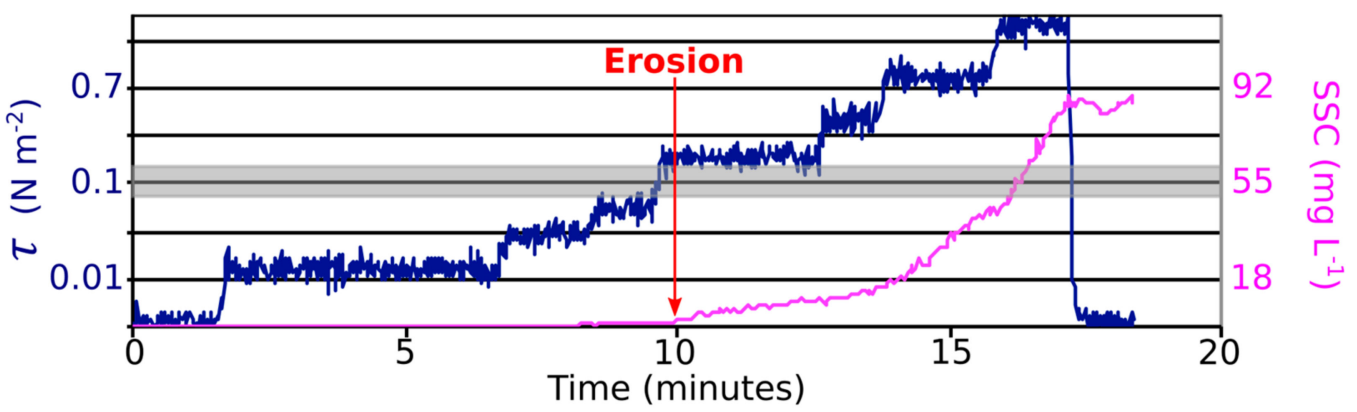

Figure 4. Erodimetry experiment conducted on a muddy sample of the BoBCS using the "erodimeter" device [7]. On the graph, the blue and pink curves represent time evolutions of bottom shear stress $\left(\mathrm{N} \cdot \mathrm{m}^{-2}\right)$ and suspended sediment concentration $\left(\right.$ SSC in $\left.\mathrm{mg} \cdot \mathrm{L}^{-1}\right)$ during the few minutes of the experiment. The applied shear stress at which erosion begins (around $0.1 \mathrm{~N} \cdot \mathrm{m}^{-2}$ ) is illustrated by a grey band.

Concerning the erosion coefficient $E_{0, m u d}$, the range of values cited in the literature extends from $10^{-3}$ to $10^{-5} \mathrm{~kg} \cdot \mathrm{m}^{-2} \cdot \mathrm{s}^{-1}$ for natural mud beds in open water (e.g., [54]). Simulating fine sediment transport along the BoBCS, Tessier et al. [43] applied the Partheniades erosion law but used an even lower erosion constant $\left(E_{0}=1.3 \times 10^{-6} \mathrm{~kg} \cdot \mathrm{m}^{-2} \cdot \mathrm{s}^{-1}\right)$. As a first attempt in the present study, a low value $E_{0, m u d}=10^{-5} \mathrm{~kg} \cdot \mathrm{m}^{-2} \cdot \mathrm{s}^{-1}$ was used, and its appropriateness was demonstrated by comparing the computed erosion fluxes ( $E_{\text {modelled }}$ ) from Equation (1) (with $\tau_{e}=\tau_{e, \text { mud }}$ and $n=n_{m u d}$ otherwise) with measurements from erodimetry experiments $\left(E_{\text {measured }}\right)$ conducted on three muddy sediment samples from the BoBCS (mud fraction higher than 70\%) (Figure 5). 


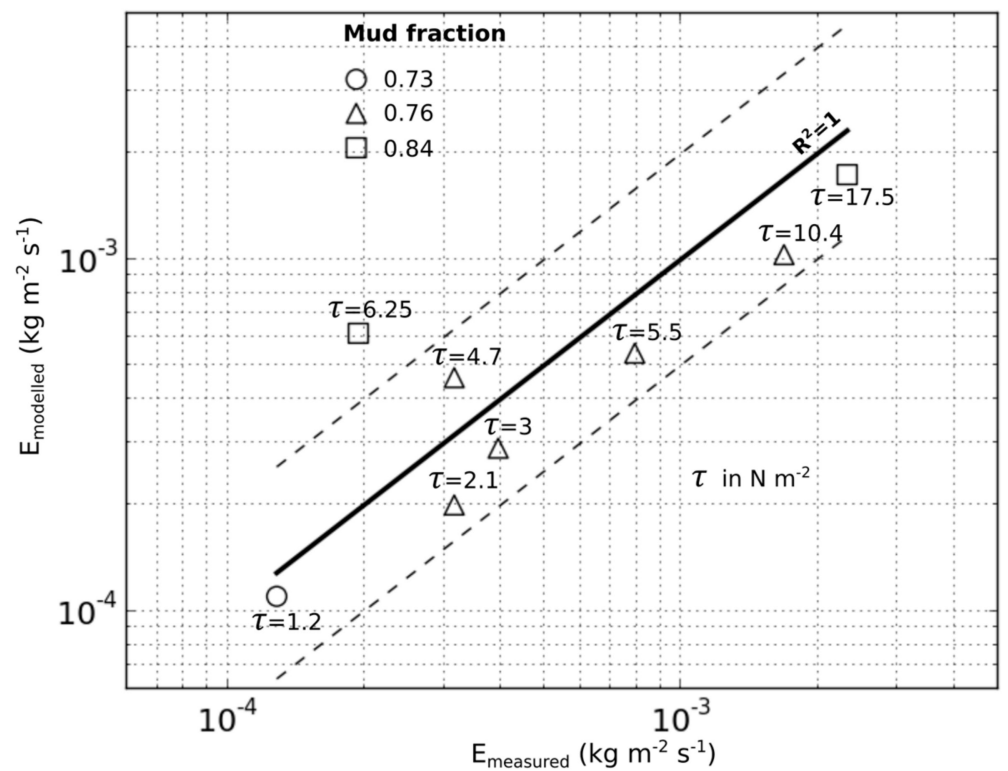

Figure 5. Comparisons of erosion fluxes deduced from erodimetry experiments conducted on muddy samples from the BoBCS and those computed from pure mud erosion law (Equation (1)) using similar shear stresses. Different symbols depict different sediment samples and labels refer to the applied shear stresses $\left(\tau\right.$ in $\mathrm{N} \cdot \mathrm{m}^{-2}$ ). The solid black line represents perfect agreement between modelled and measured fluxes, and the dotted lines delimit the range linked to model overestimation or underestimation by a factor 2 .

The above-mentioned $E_{0, m u d}, \tau_{e, m u d}$, and $n_{m u d}$ values are summarized in Table 2 and constitute reference parameters characterizing pure mud erosion.

\subsection{Erosion of Transitional Sand/Mud Mixtures: Selection of Transition Formulations to be Tested}

Between critical mud fractions $\left(f_{m c r 1}\right.$ and $\left.f_{m c r 2}\right), E_{0}, \tau_{e}$, and $n$ ranged between pure sand $\left(E_{0, \text { sand }}\right.$, $\tau_{e, \text { sand }}$, and $\left.n_{\text {sand }}\right)$ and pure mud $\left(E_{0, m u d}, \tau_{e, m u d}\right.$, and $\left.n_{m u d}\right)$ parameters, following a transition trend which had to be specified. We defined several expressions of the erosion law for the transition between non-cohesive and cohesive behaviours as a function of the surficial sediment mud fraction $\left(f_{m}\right)$.

First, we considered a linear transition type in which erosion-related parameters are linearly interpolated from the respective sand and mud parameters according to their respective concentrations in the mixture (default solution in the original paper by Le Hir et al. [1]).

Several experimental studies in the literature revealed that the transition from non-cohesive to cohesive could be more abrupt. For instance, Smith et al. [17] performed erodibility experiments on natural and artificial sand/mud mixtures, and showed a rapid decrease in erosion rates with increasing mud/clay contents. Nevertheless, the transition between the two regimes remains poorly documented. Here, we propose an exponential formulation that specifically enables adjustment of the sharpness of the transition, which is not possible with the few existing expressions (e.g., $[1,19,20,23,24])$. The exponential transition trend (Equation (10)) was applied to all erosion-related parameters $\left(X_{\text {exp }}\right)$ as a function of mud content, with a coefficient $C_{\exp }$ allowing the adjustment of the sharpness of the transition, which becomes more abrupt with an increase in $C_{\text {exp }}$ :

$$
X_{\text {exp }}=\left(X_{\text {sand }}-X_{\text {mud }}\right) e^{C_{\text {exp }} \cdot P_{\text {exp }}}+X_{\text {mud }}
$$

where $P_{\text {exp }}=\left(f_{m c r 1}-f_{m}\right) /\left(f_{m c r 2}-f_{m c r 1}\right) ; X_{\text {sand }}=\left\{E_{0, \text { sand }} ; \tau_{e, \text { sand }} ; n_{\text {sand }}\right\} ;$ and $X_{\text {mud }}=\left\{E_{0, m u d} ; \tau_{e, m u d} ; n_{m u d}\right\}$.

Different settings of the erosion law were tested in 3D simulations to assess the correctness of the model response in terms of SSC and changes in the seabed. All settings are illustrated in Figure 6. Three kinds of transition, one linear, and two exponentials (with $C_{\exp }=10$ and 40 in Equation (10)), were 
defined to evaluate the effect of the transition trend only, using the reference critical mud fractions $\left(f_{m c r}\right.$ $=20 \%$ and $f_{m c r 2}=70 \%$ ). The corresponding settings are named $S 1_{L I N}, S 1_{E X P 1}$, and $S 1_{E X P 2}$, respectively.
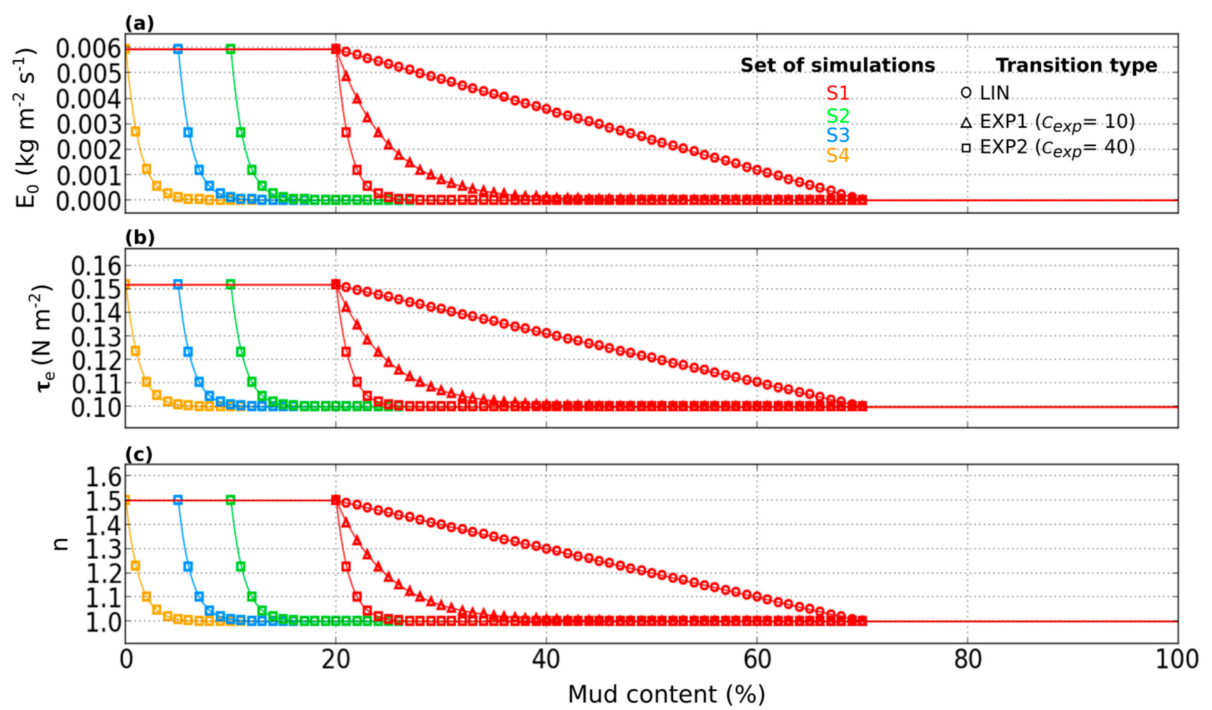

Figure 6. Variations in erosion-related parameters (erodibility parameter $E_{0}(\mathbf{a})$; critical shear stress $\tau_{e}$ (b); and exponent $n$ (c); used in the erosion law (Equation (1)) as a function of the surficial sediment mud content in the different erosion settings tested.

A second series of simulations was run to evaluate the sensitivity of the results to critical mud fraction values. Thus, the $f_{m c r 1}$ value was successively reduced to $10 \%, 5 \%$, and $\sim 0 \%$ (with the corresponding $f_{m c r 2}=60 \%, 55 \%$, and $50 \%$ ), but only the exponential transition regime (with $C_{\exp }=40$ ) was considered (simulations $S 2_{E X P 2}, S 3_{E X P 2}$, and $S 4_{E X P 2}$ respectively), as it produced better results than the other transitions (see results Section 4.1).

\section{Results}

\subsection{Influence of the Transition Trend between Non-Cohesive and Cohesive Erosion Modes in the Erosion Law}

The first step consisted in assessing the 3D model response in the model cell located closest to the $L C$ station in terms of SSC and changes in the seabed (i.e., composition, thickness) by considering two transitions of the erosion law, one linear and one exponential (with $C_{\text {exp }}=40$ in Equation (10)), between the non-cohesive and cohesive regimes (Figure 7). This first comparison was performed using the "reference" $f_{m c r 1}$ and $f_{m c r 2}$ values of $20 \%$ and $70 \%$, respectively. The two erosion settings, $S 1_{L I N}$ and $S 1_{E X P 2}$, are illustrated in Figure 6 (Section 3.4).

Total bottom shear stresses (i.e., those caused by waves and currents) and barotropic currents in Figure 7a illustrate changes in forcing throughout the period. In the water column, we successively represented SSC over the entire water column (Figure $7 \mathrm{~b}-\mathrm{d}$ ) and at $1.67 \mathrm{~m}$ above the seabed (i.e., at the level of the first $A W A C$ cell; Figure 7e) for the two simulations and for the $A W A C$ measurements. Changes in the seabed in the two simulations are presented in Figure 7f,g. Lastly, a global sediment budget (in $\mathrm{kg}$ ) was applied to the model cell used for the comparison, and the contribution of advection (hereafter referred to as $F_{O B C}$ with $F_{O B C \text {, mud }}$ for mud and $F_{O B C \text {, sand }}$ for sand, representing the total amount (integrated) of sediment that crosses the borders of the cells along the water column, as net inflow if $F_{O B C}$ increases or as net outflow if $F_{O B C}$ decreases) is illustrated in Figure $7 \mathrm{~h}$. 


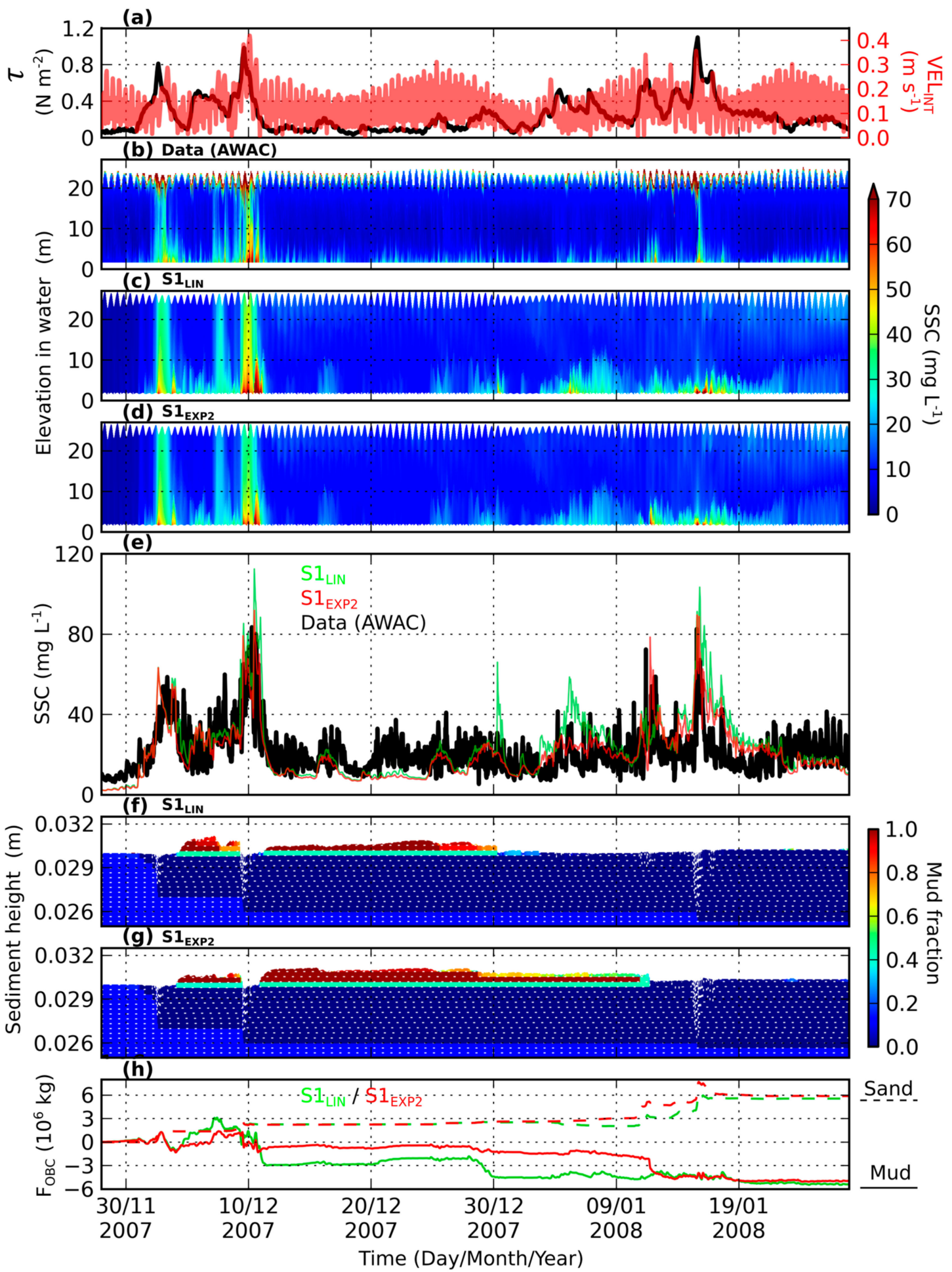

Figure 7. Comparisons of the results of the $3 \mathrm{D}$ model obtained from erosion settings $S 1_{L I N}$ and $S 1_{E X P 2}$, and measurements made by the $A W A C$ acoustic profiler. (a) Shear stresses $\tau$ and depth-integrated currents $V E L_{I N T} ;(\mathbf{b})$ measured $S S C$ over the entire water column; (c,d) computed SSC for $S 1_{L I N}$ and $S 1_{E X P 2}$ simulations; (e) time series of measured and modelled SSC variations at the level of the AWAC first cell (1.67 $\mathrm{m}$ above the bottom); (f,g) changes in the seabed (mud fraction, thickness of the sediment layers) in the two simulations (white dotted lines represent the boundaries of the sediment layers); and (h) integrated amount of SSC advected through the water column (solid lines represent mud and dotted lines represent sand). 
Regarding the dynamics of sediments in suspension, SSC from the AWAC profiler ranged between 10 and $80 \mathrm{mg} \cdot \mathrm{L}^{-1}$ over the study period. Four main resuspension events can be identified: the first event lasted from 1 to 5 December 2007 (Event 1), the second from 8 to 11 December 2007 (Event 2), the third from 11 to 12 January 2008 (Event 3), and the last from 15 to 17 January 2008 (Event 4). During these events, SSC values ranged between 20 and $80 \mathrm{mg} \cdot \mathrm{L}^{-1}$ near the seabed, and did not exceed $40 \mathrm{mg} \cdot \mathrm{L}^{-1}$ close to the surface (Figure 7). The rest of the time, a higher frequency turbidity signal linked to the semi-diurnal tide resuspension was recorded near the seabed with SSC in the range of $10-15 \mathrm{mg} \cdot \mathrm{L}^{-1}$. Turbidity peaks were regularly detected in the surface signal whereas there was no significant increase near the seabed: these peaks are probably due to the signal diffraction caused by wave-induced air bubbles (wave mixing; see Tessier [55]). Such a phenomenon also occurs during energetic events $\left(H_{S}>2 \mathrm{~m}\right)$ with a SSC signal in the surface higher than in the rest of the water column.

Despite the fact that the model response generally agreed with observations, computing SSC with the $S 1_{\text {LIN }}$ erosion setting highlighted some periods during which turbidity was overestimated, for instance in the upper half of the water column during Event 2, and several times between 30 December and 9 January (Figure 7c,e). Overestimations were particularly noticeable in the SSC series at $1.67 \mathrm{~m}$ above the seabed (Figure 7e): modelled SSC regularly exceeded observed SSC by 20 to $40 \mathrm{mg} \cdot \mathrm{L}^{-1}$ during Events 2 and 4, and even during calmer periods (e.g., between 30 December and 9 January). In contrast, modelled SSC were underestimated by a factor of 2 during Event 3 . The $S 1_{\text {LIN }}$ erosion setting led to a representation of observed SSC with a RMSE of $14 \mathrm{mg} \cdot \mathrm{L}^{-1}$ over the study period.

Using the $S 1_{\text {EXP2 }}$ erosion setting enabled a general improvement in modelled SSC with a RMSE of $10.5 \mathrm{mg} \cdot \mathrm{L}^{-1}$ over the period, and a correct response during the four energetic periods (Figure $7 \mathrm{~d}, \mathrm{e}$ ). Differences in SSC between simulations during Events 1, 2, and 4 were mainly due to different erosion rates (especially due to $E_{0}$ in Equation (1)) prescribed for the same intermediate mud fraction in the surficial layer (in Figure 6a, this rate is clearly higher in the $S 1_{L I N}$ setting). However, other differences, especially between 30 of December and 9 of January and during Event 3, are linked to the contrasted changes in the seabed between the two simulations.

One major difference in these changes occurs after Event 2 with more significant mud deposition in simulation $S 1_{\text {EXP2 }}$ (Figure $7 \mathrm{f}, \mathrm{g}$ ). This difference can also be seen in Figure $7 \mathrm{~h}$, which highlights a significant decrease in $F_{O B C}$, mud (i.e., flow of mud out of the cell) in simulation $S 1_{\text {LIN }}$, but not in $S 1_{E X P 2}$. The decrease in $F_{O B C}$, mud in simulation $S 1_{L I N}$ is probably due to less mud inputs from adjacent cells, resulting in relatively more mud exported by advection and thus less mud deposition during the decrease in shear stress following Event 2. Note that this difference in seabed changes influences the sediment dynamics in both simulations throughout the period. Following Event 2, a transition in surficial sediment from muddy to sandy occurs in both simulations but at different times. In the $S 1_{L I N}$ simulation, the transition occurs half way through the period, around 30 December, and manifests itself as a SSC peak linked to mud resuspension near the bottom (Figure 7e), and by a decrease in $F_{O B C \text {, mud }}$ (relative loss by advection), which does not occur in the $S 1_{E X P 2}$ simulation. Following the transition in the nature of the seabed, the $S 1_{L I N}$ simulation regularly gives incorrect $S S C$ responses (e.g., overestimation around 6 January, underestimation during Event 3). These results underline the potential role of advection processes in the contrasted results of the two simulations, and the need for full 3D modelling to obtain a final fit of the erosion law. In the $S 1_{E X P 2}$ simulation, the transition occurs later in the period, around 11 of January, and enables a correct SSC response regarding Event 3 , associated with a decrease in $F_{O B C}$, mud. It may mean that, on the one hand, setting $S 1_{E X P 2}$ allows a more accurate representation of resuspension dynamics in response to a given forcing, and on the other hand, it induces a more correct change in the nature of the seabed with respect to the variations in forcing over time. Note that despite contrasted sediment dynamics in the different simulations, the mud budget at the scale of the cell summed over the whole period led to similar trends corresponding to a relative loss by advection of around $-5 \times 10^{6} \mathrm{~kg}$ (that is $-5 / 2.5^{2} \mathrm{~kg} \cdot \mathrm{m}^{-2}$ ).

Sand contributes to turbidity over shorter periods than mud, mainly during Events 1, 2, and 4. Results provide evidence that sand is not subject to the same dynamics as mud. Until the transition in 
the nature of the surficial sediments in the middle of the period (30 December), sand dynamics appear to be quite similar in the two simulations (e.g., $F_{O B C}$, sand in Figure $7 \mathrm{~h}$ ). Beyond this date, the contrasted nature of the seabed results in more regular sand resuspension in $S 1_{L I N}$, with an advection component leading to a relative local sand loss (in the cell). Starting from Event 3, $F_{O B C}$, sand increases (i.e., relative sand inflow into the cell) in both simulations while the advection flux of mud decreases (in $S 1_{E X P 2}$ ) or does not change (in $S 1_{L I N}$ ). This highlights the fact that sand and mud dynamics are likely to differ depending on the nature of the seabed in adjacent cells.

The erosion setting $S 1_{E X P 1}$, which is characterized by a less abrupt exponential transition in erosion law $\left(C_{\text {exp }}=10\right.$ in Equation (10)), appears to be less accurate in terms of SSC (not illustrated here) with a RMSE of $12 \mathrm{mg} \cdot \mathrm{L}^{-1}$ over the study period (versus $10.5 \mathrm{mg} \cdot \mathrm{L}^{-1}$ in $S 1_{E X P 2}$ ). The turbidity response provided by the model would be expected to be degraded while progressively reducing the decreasing trend of the transition (until a linear decrease is reached).

Considering the accurate representation of resuspension events and the lower RMSE obtained with the erosion setting $S 1_{E X P 2}$, the latter was considered as an "optimum" setting, suggesting that the definition of an exponential transition to describe sand/mud mixture erosion between non-cohesive and cohesive erosion modes may be appropriate in hydro-sedimentary numerical models.

\subsection{Influence of Critical Mud Fractions}

The sensitivity of the $S S C$ model results to critical mud fractions, $f_{m c r 1}$ and $f_{m c r 2}$, was assessed, starting from the "optimum" erosion setting deduced in Section 4.1 and characterized by an exponential transition between $f_{m c r 1}=20 \%$ and $f_{m c r 2}=70 \%$ with $C_{\exp }=40$ in Equation (10) (i.e., $S 1_{E X P 2}$ setting). Both critical mud fractions were progressively reduced by $10 \%\left(f_{\text {mcr } 1}=10 \%, f_{m c r 2}=60 \%\right), 15 \%$ $\left(f_{m c r 1}=5 \%, f_{m c r 2}=55 \%\right)$, and $20 \%\left(f_{m c r 1} \approx 0 \%, f_{m c r 2}=50 \%\right)$. The corresponding settings, $S 2_{E X P 2}$, $S 3_{E X P 2}$, and $S 4_{E X P 2}$ are illustrated in Figure 6. Results linked to the application of these different settings are illustrated in Figure 8 . Note that the second critical mud fraction $f_{m c r 2}$ appears in the extension of the exponential decay (Equation (10)), but, due to the shape of the exponential trend, it does not constitute a real critical mud fraction but rather an adjustment parameter for the transition. We can thus consider that this sensitivity analysis mainly deals with the setting of the first critical mud fraction $f_{m c r 1}$.

First, it can be seen that the SSC linked to the four resuspension events progressively decrease with the decrease in $f_{m c r}$ (Figure $8 \mathrm{~b}$ ), which results in underestimation of turbidity with respect to observed values. While no clear differences in SSC appear between $S 1_{E X P 2}$ and $S 2_{E X P 2}$ (the latter is not illustrated in Figure 8), i.e., with a reduction of $f_{m c r 1}$ from $20 \%$ to $10 \%$, significant SSC underestimations occur for $f_{m c r}<10 \%$. The average turbidity during resuspension events is underestimated by 15-20\% (respectively, 30\%) in simulation $S 3_{\text {EXP2 }}$ (respectively, $S 4_{E X P 2}$ ). Regarding maximum SSC, underestimations of SSC peaks are around 15-30\% (respectively, 40-50\%) during Events 1 and 2 in simulation $S 3_{E X P 2}$ (respectively, $S 4_{E X P 2}$ ). In addition, SSC peaks during Events 3 and 4 are completely absent in these two simulations with an underestimation of about $60 \%$. Other simulations with linear trend but low $f_{m c r 1}$ were tested and showed no improvement compared with the settings illustrated in Figures 7 and 8.

Changes in the seabed linked to the optimum erosion setting $S 1_{E X P 2}$ and the simulation $S 3_{E X P 2}$ $\left(f_{m c r 1}=5 \%\right)$ are illustrated in Figure 8c,d. Following Event 2, contrary to results in $S 1_{E X P 2}$, no drastic change in the nature of the seabed occurs in $S 3_{E X P 2}$ in the rest of the period, with a surficial sediment containing at least $30-40 \%$ of mud. This less dynamic change in the seabed is consistent with the lower SSC obtained in the water column. A reduction of $f_{m c r 1}$ led to the application of a pure mud erosion law starting from a lower mud content in the surficial sediment. This mostly resulted in less erosion $\left(E_{0, m u d}<<E_{0, \text { sand }}\right)$ with weaker SSC and slower changes in the seabed. This is also visible in the variations in $F_{O B C, \text { mud }}$ (Figure 8e) which highlight the fact that the reduced sediment dynamics obtained by reducing $f_{m c r}$ results in weaker gradients (SSC, seabed nature) with adjacent cells, and a less dynamic advection term over the study period. 


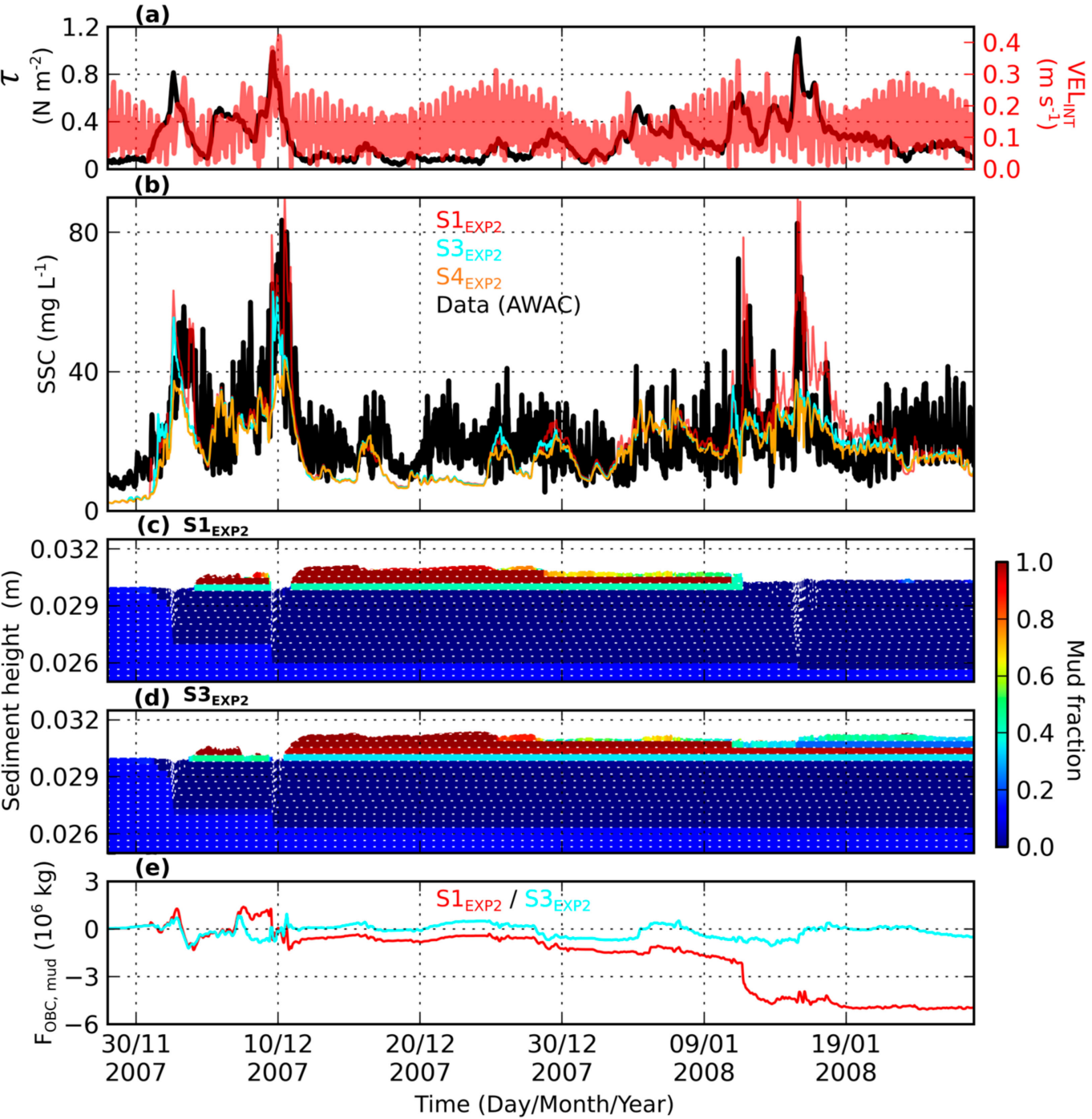

Figure 8. Comparisons of the results of the $3 \mathrm{D}$ model obtained from erosion settings $S 1_{E X P 2}, S 3_{E X P 2}$ and $S 4_{E X P 2}$, and measurements made with the $A W A C$ acoustic profiler. (a) Shear stresses $\tau$ and depth-integrated currents $V E L_{I N T}$; (b) time series of measured and modelled SSC at the level of the first AWAC cell (1.67 m above the bottom); (c,d) changes in the seabed (mud fraction, thickness of the sediment layers) in $S 1_{E X P 2}$ and $S 3_{E X P 2}$ simulations (the white dotted lines represent the boundaries of the sediment layers); and (e) integrated amount of mud advected through the water column in the $S 1_{E X P 2}$ and $S 3_{E X P 2}$ simulations.

\section{Discussion}

\subsection{Setting Describing Erosion of a Sand/Mud Mixture}

All experimental studies in the literature on the erosion of sand/mud mixtures mentioned a transition in the erosion mode when fine particles progressively fill the spaces between non-cohesive particles. Panagiotopoulos et al. [15] proposed a conceptual model showing the mechanism for the initiation of sediment motion for sand-mud mixtures, based on the forces acting on an individual grain and the associated angle of internal friction. When the mud content increases, clay minerals progressively fill the spaces between the sand particles, which slightly alters the pivoting characteristics and consequently the internal friction angle, and thus a slight change in erosion resistance. As soon as the sand particles are no longer in contact with one another, pivoting stops being the main mechanism behind the initiation of motion, and the resistance of the clay fraction mainly controls 
erosion. Depending on the authors, this transition is expressed by reasoning in terms of mud or clay content in the mixture. For instance, Mitchener and Torfs [14] proposed a transition between 3\% and $15 \%$ mud content, and suggested using cohesive-type sediment transport equations above this transition value and sand transport theories below it. Other authors suggested that the transition occurs at much higher mud content, i.e., between $20 \%$ and $30 \%$ (e.g., $[7,15])$. More generally, previous investigations emphasized that only $2 \%$ to $10 \%$ of clay minerals (dry weight) added in a non-cohesive sediment matrix were sufficient to control the soil properties and increase the resistance of the bed to erosion (e.g., $[17,24,45,56])$.

Modelling results in the present study highlighted the fact that the critical mud fraction $\left(f_{m c r 1}\right)$, above which a transition toward a cohesive erosion mode would start, is at least $10 \%$ mud content. Grain size analyses of numerous sediment samples (from several locations, and at different depths in the sediment) from the BoBCS revealed that the clay content (per cent $<4 \mu \mathrm{m}$ ) corresponds to $30 \%$ $\left( \pm 3 \%, R^{2}=0.96\right)$ of the mud content (per cent $\left.<63 \mu \mathrm{m}\right)$. Such a constant ratio between the clay and mud fractions (or between the clay and silt fractions) in a given area has been observed in many sites worldwide (e.g., [13]). Thus, the critical clay content deduced from our modelling fitting would be around $3 \%$. Therefore, our results are in agreement with experimental results of previous studies regarding the existence and the value of a critical mud/clay fraction indicating a transition in the mode of erosion.

Multiple transition trends of the erosion law (linear, exponentials) were tested to describe the erosion behaviour of transitional sand/mud mixtures, i.e., when the mud fraction exceeds the critical value of $f_{m c r}$ in the mixture. The quality of the model response was evaluated by comparing SSC results with turbidity measurements provided by the $A W A C$ profiler over the entire water column. Based on RMSE and average or maximum SSC values reached during resuspension events, the results provided a more accurate representation of observations while considering an abrupt exponential transition of erosion parameters (i.e., $E_{0}, \tau_{e}$, and $n$ in the Partheniades form of the erosion law, see Equation (1)). Actually, changes in SSC produced by this transition formulation mainly hold in the contrasted $E_{0}$ values prescribed in erosion law depending on the seabed mud fraction $\left(E_{0, \text { mud }}<<E_{0, \text { sand }}\right.$; see Table 2). This result agrees with results recently obtained by Smith et al. [17] who performed erosion experiments on mixed sediment beds prepared in the laboratory $(250-500 \mu \mathrm{m}$ sands mixed with different clayey sediments corresponding to kaolinite or kaolinite/bentonite). In particular, they observed a rapid decrease in erosion rates, from 1.5 to 2.5 orders of magnitude, over a range of $2 \%$ to $10 \%$ clay content. In the present study, exponential transitions prescribed in settings $S 1_{E X P 1}$ and $S 1_{\text {EXP2 }}\left(C_{\exp }=10\right.$ and $C_{\exp }=40$ in Equation (10), Figure 6) led to a variation in the erodibility parameter $E_{0}$ of about 2.5 orders of magnitude over a mud content range of $10 \%$ and $40 \%$, i.e., over a clay content ranging from $3 \%$ and $12 \%$ respectively. The best model results obtained from erosion setting $S 1_{E X P 2}$ are thus consistent with the findings of Smith et al. [17], and suggest that a rapid exponential transition may be appropriate to describe the erosion of a sand/mud mixture between non-cohesive and cohesive erosion modes in numerical hydro-sedimentary models.

\subsection{Limitations of the Approach and Remaining Uncertainties}

Despite successive assessments of model quality, some limitations and uncertainties concerning our modelling approach remain and have to be addressed.

\subsubsection{Mud Erosion Law}

A pure mud erosion law was set up based on erodimetry experiments performed on muddy sediment samples from the BoBCS. A critical shear stress for mud erosion $\left(\tau_{e, m u d}\right)$ of $0.1 \mathrm{~N} \cdot \mathrm{m}^{-2}$ was deduced. By combining this $\tau_{e, m u d}$ value with the minimum erodibility parameter $E_{0, m u d}$ recommended by e.g., Winterwerp [54], i.e., $10^{-5} \mathrm{~kg} \cdot \mathrm{m}^{-2} \cdot \mathrm{s}^{-1}$, the application of the mud erosion law from the model (Section 3.3) led to good agreement between modelled erosion fluxes and those obtained in erodimetry experiments for comparable applied shear stresses (Figure 5). Such a lower critical stress for erosion 
when the mixture is muddier is opposite to trends most often published, characterized by an increase of the resistance to erosion when mud is added to sand (e.g., [6,7,14-17]). Other simulations were performed with higher $\tau_{e, \text { mud }}$ values, $0.15,0.2$, and $0.4 \mathrm{~N} \cdot \mathrm{m}^{-2}$. As expected, modelled SSC was underestimated compared with observed SSC while $\tau_{e, \text { mud }}$ increased (even for $0.15 \mathrm{~N} \cdot \mathrm{m}^{-2}$ ). Another assessment of $E_{0, m u d}$ could have produced similar results, but we preferred to keep the shear strength provided by our experiments, the low value being justified by the fact that in our environment (erosion on a continental shelf with low bottom friction) the sediment is never remobilized at depth, and the surficial sediment remains unconsolidated.

\subsubsection{Initial Condition of the Sediment and Time Variation of the Seabed}

Seabed initialization was prescribed from the synthesis of sediment facies applied at the beginning of each simulation. To evaluate the influence of the sediment initialization on model results (SSC, seabed variations), the "optimum" model setting from the present study $\left(S 1_{E X P 2}\right)$ was used again in a new simulation using the surficial sediment cover computed at the end of a one-year simulation used as spin up. We obtained similar SSC results with a RMSE of $11.3 \mathrm{mg} \cdot \mathrm{L}^{-1}$ over the study period (versus $10.5 \mathrm{mg} \cdot \mathrm{L}^{-1}$ in the original $S 1_{E X P 2}$ simulation). Similarities in seabed variations (thickness and composition) in the two simulations were likewise remarkable (not illustrated here). Thus, the seabed initialization prescribed at the beginning of each simulation appears to be appropriate and does not correspond to a transitional state regarding the sediment dynamics.

Model results concerning changes in the seabed highlighted pronounced gradients in the nature of the surficial sediment in most simulations, with an alternation of muddy and sandy facies depending on the intensity of forcing (e.g., shear stress, advection). Such variations in the nature of the sediment are not unrealistic, since grain size analyses of a sediment core sampled at $L C$ station revealed a layered bed, with alternating muddy and sandy layers at different depths in the sediment. These variations are also consistent with the geographical location of $L C$ station (Figure 1), in a zone with horizontal gradients in sediment facies.

A further validation of the model in terms of thickness or elevation would require other measurements as in situ altimetry data (e.g., [57]). Simulations make it necessary to use altimetry data, which were not available in the present study.

\subsubsection{Applicability of the Sand/Mud Mixture Erosion Law}

Assessment of the effect of erosion settings on the quality of model results with respect to observations would require further comparisons in other study sites where the seabed consists of both sand and mud. This would make it possible to know if an abrupt transition between non-cohesive and cohesive erosion modes systematically improves model accuracy in terms of SSC.

The use of the sand/mud mixture erosion law derived from this study requires site-specific information beforehand, in particular grain size analyses for the assessment of the mud or the clay content. Since the critical mud fraction $f_{m c r 1}$, above which erosion behaviour starts to change, mainly depends on clay content, the ratio between clay and mud fractions can be used. In future works, it would be interesting to explore other mud properties than grain size and sediment fractions, such as mineralogy, to represent more accurately the key role played by cohesive sediments in erosion process, especially for transitional sand/mud mixtures between the contrasted non-cohesive/cohesive regimes.

Lastly, the formulation of erosion was based on the Patheniades-Ariathurai law, with an erosion flux proportional to the normalized excess shear stress $\left(\tau / \tau_{e}-1\right)$. Such a formulation is very sensitive to the value of the critical shear stress for erosion, which can be difficult to estimate and highly variable in the case of sand/mud mixtures. Alternatively, a formulation of the erosion flux proportional to the excess shear stress $\left(\tau-\tau_{e}\right)$ would reduce the sensitivity of erosion to $\tau_{e}$. It would also be in agreement with the Van Kesteren-Winterwerp-Jacobs erosion law [6,58], and deserves further investigations following the pioneering work of Jacobs et al. [6]. 


\section{Conclusions}

The aim of this study was to assess the influence of the erosion law prescribed in a 3D realistic hydro-sedimentary model on sediment dynamics in the case of a seabed composed of both fine sand and mud in a slightly energetic environment, representative of continental shelves. According to the sediment model described by Le Hir et al. [1], the sediment was eroded as a mixture and was assumed to behave as pure sand below a first critical mud fraction in the surficial sediment, and as pure mud above a second one. Following hydrodynamic validation of the model and rigorous assessment of pure sand and pure mud erosion dynamics, several transition trends of erosion-related parameters (erodibility parameter, critical shear stress, and exponent in the Partheniades erosion law) were tested to describe the erosion of transitional sand/mud mixtures between the two critical fractions. Different simulations were run using linear or exponential transitions, and different critical mud fractions. The accuracy of model results regarding suspended matter dynamics was evaluated at a single point, located on the Bay of Biscay shelf, by performing comparisons with turbidity observations provided by an acoustic profiler during two typical winter months. The main conclusions of this work are:

- Using an abrupt exponential transition, e.g., an erodibility parameter decrease of 2.5 orders of magnitude over a 10\% (respectively, 3\%) mud (respectively, clay) content range, improves SSC model results regarding measurements, compared to results obtained with linear or less abrupt exponential transitions. This conclusion agrees with recent experimental studies in the literature on the erosion of sand/mud mixtures, which mention a drastic change in erosion mode for only a small percentage of clay added in the mixture.

- A first critical mud fraction (above which the erosion mode begins to change) of 10-20\% is required to ensure a relevant model response in turbidity. By reasoning in terms of the clay fraction, the corresponding critical clay fraction ranges between $3 \%$ and $6 \%$. Once again, this conclusion agrees with experimental studies in the literature reporting that $2 \%$ to $10 \%$ of clay minerals in a sediment mixture are sufficient to control the soil properties.

- The erosion flux of mixed sediments appears to be very sensitive to the clay fraction of the surficial sediment, and then is likely to change considerably at a given location, according to erosion and deposition events.

- The need to perform 3D simulations to account for advection, which considerably influences sediment dynamics in terms of export of resuspended sediments, sediment inflows from adjacent cells, and consequent changes in the surficial seabed (nature and thickness of deposits).

Therefore, the optimal erosion law derived from this study to describe sand/mud mixture erosion led to model results consistent with measurements and with most of the conclusions deduced from experimental studies already published. This should encourage further similar comparisons and suggests that the application of this kind of erosion setting is appropriate for hydro-sedimentary models.

Acknowledgments: This study was supported by the SHOM (Service Hydrographique et Océanographique de la Marine) and IFREMER (Institut Français de Recherche pour l'Exploitation de la Mer). The authors would like to thank the SHOM for surficial mud content data. Lastly, the two anonymous reviewers are deeply thanked for their comments and suggestions that greatly improved the manuscript.

Author Contributions: All authors conceived the study; B.M., P.L.H., and F.C. designed the numerical experiments; T.G. performed the seabed initialization of the model describing the horizontal distribution of sediment facies; B.M. performed the simulations; B.M., P.L.H. and F.C. analysed the simulations; and B.M. and P.L.H. wrote the paper.

Conflicts of Interest: The authors declare no conflict of interest.

\section{References}

1. Le Hir, P.; Cayocca, F.; Waeles, B. Dynamics of sand and mud mixtures: A multiprocess-based modelling strategy. Cont. Shelf Res. 2011, 31, S135-S149. [CrossRef] 
2. Righetti, M.; Lucarelli, C. May the Shields theory be extended to cohesive and adhesive benthic sediments? J. Geophys. Res. 2007, 112, C05039. [CrossRef]

3. Kimiaghalam, N.; Clark, S.P.; Ahmari, H. An experimental study on the effects of physical, mechanical, and electrochemical properties of natural cohesive soils on critical shear stress and erosion rate. Int. J. Sediment Res. 2016, 31, 1-15. [CrossRef]

4. Williamson, H.J.; Ockenden, M.C. Laboratory and field investigations of mud and sand mixtures. In Proceedings of the First International Conference on Hydro-Science and Engineering, Advances in Hydro-Science and Engineering, Washington, DC, USA, 7-11 June 1993; Wang, S.S.Y., Ed.; Volume 1, pp. 622-629.

5. Le Hir, P.; Monbet, Y.; Orvain, F. Sediment erodability in sediment transport modelling: Can we account for biota effects? Cont. Shelf Res. 2007, 27, 1116-1142. [CrossRef]

6. Jacobs, W.; Le Hir, P.; Van Kesteren, W.; Cann, P. Erosion threshold of sand-mud mixtures. Cont. Shelf Res. 2011, 31, S14-S25. [CrossRef]

7. Le Hir, P.; Cann, P.; Waeles, B.; Jestin, H.; Bassoullet, P. Erodibility of natural sediments: Experiments on sand/mud mixtures from laboratory and field erosion tests. In Sediment and Ecohydraulics: INTERCOH 2005 (Proceedings in Marine Science); Kusuda, T., Yamanishi, H., Spearman, J., Gailani, J.Z., Eds.; Elsevier: Amsterdam, The Netherlands, 2008; Volume 9, pp. 137-153.

8. Van Rijn, L.C. Sediment pick-up functions. J. Hydraul. Eng. 1984, 110, 1494-1502. [CrossRef]

9. Emadzadeh, A.; Cheng, N.S. Sediment pickup rate in uniform open channel flows. In Proceedings of the River Flow 2016, Iowa City, IA, USA, 11-14 July 2016; Constantinescu, G., Garcia, M., Hanes, D., Eds.; Taylor \& Francis Group: London, UK, 2016; Volume 1, pp. 450-457.

10. Partheniades, E. A Study of Erosion and Deposition of Cohesive Soils in Salt Water. Ph.D. Thesis, University of California, Berkeley, CA, USA, 1962.

11. Ariathurai, C.R. A Finite Element Model of Cohesive Sediment Transportation. Ph.D. Thesis, University of California, Davis, CA, USA, 1974.

12. Van Ledden, M.; Van Kesteren, W.G.M.; Winterwerp, J.C. A conceptual framework for the erosion behaviour of sand-mud mixtures. Cont. Shelf Res. 2004, 24, 1-11. [CrossRef]

13. Flemming, B.W. A revised textural classification of gravel-free muddy sediments on the basis of ternary diagrams. Cont. Shelf Res. 2000, 20, 1125-1137.

14. Mitchener, H.; Torfs, H. Erosion of mud/sand mixtures. Coast. Eng. 1996, 29, 1-25. [CrossRef]

15. Panagiotopoulos, I.; Voulgaris, G.; Collins, M.B. The influence of clay on the threshold of movement of fine sandy beds. Coast. Eng. 1997, 32, 19-43. [CrossRef]

16. Ye, Z.; Cheng, L.; Zang, Z. Experimental study of erosion threshold of reconstituted sediments. In Proceedings of the ASME 2011 30th International Conference on Ocean, Offshore and Arctic Engineering, Rotterdam, The Netherlands, 19-24 June 2011; American Society of Mechanical Engineers: New York, NY, USA; Volume 7, pp. 973-983. [CrossRef]

17. Smith, S.J.; Perkey, D.; Priestas, A. Erosion thresholds and rates for sand-mud mixtures. In Proceedings of the 13th International Conference on Cohesive Sediment Transport Processes (INTERCOH), Leuven, Belgium, 7-11 September 2015; Toorman, E., Mertens, T., Fettweis, M., Vanlede, J., Eds.;

18. Gailani, J.Z.; Jin, L.; McNeil, J.; Lick, W. Effects of Bentonite Clay on Sediment Erosion Rates. DOER Technical Notes Collection. Available online: http: / www.dtic.mil/docs/citations / ADA390214 (accessed on 21 July 2017).

19. Waeles, B.; Le Hir, P.; Lesueur, P. A 3D morphodynamic process-based modelling of a mixed sand/mud coastal environment: The Seine estuary, France. In Sediment and Ecohydraulics: INTERCOH 2005, Proceedings in Marine Science; Kusuda, T., Yamanishi, H., Spearman, J., Gailani, J.Z., Eds.; Elsevier: Amsterdam, The Netherlands, 2008; Volume 9, pp. 477-498.

20. Bi, Q.; Toorman, E.A. Mixed-sediment transport modelling in Scheldt estuary with a physics-based bottom friction law. Ocean Dyn. 2015, 65, 555-587. [CrossRef]

21. Migniot, C. Tassement et rhéologie des vases-Première partie. La Houille Blanche 1989, 1, 11-29. (In French) [CrossRef]

22. Dickhudt, P.J.; Friedrichs, C.T.; Sanford, L.P. Mud matrix solids fraction and bed erodibility in the York River estuary, USA, and other muddy environments. Cont. Shelf Res. 2011, 31, S3-S13. [CrossRef] 
23. Carniello, L.; Defina, A.; D'Alpaos, L. Modeling sand-mud transport induced by tidal currents and wind waves in shallow microtidal basins: Application to the Venice Lagoon (Italy). Estuar. Coast. Shelf Sci. 2012, 102, 105-115. [CrossRef]

24. Van Ledden, M. Sand-Mud Segregation in Estuaries and Tidal Basins. Ph.D. Thesis, Delft University of Civil Engineering, Delft, The Netherlands, 2003.

25. Ahmad, M.F.; Dong, P.; Mamat, M.; Wan Nik, W.B.; Mohd, M.H. The critical shear stresses for sand and mud mixture. Appl. Math. Sci. 2011, 5, 53-71.

26. Wiberg, P.L.; Drake, D.E.; Harris, C.K.; Noble, M. Sediment transport on the Palos Verdes shelf over seasonal to decadal time scales. Cont. Shelf Res. 2002, 22, 987-1004. [CrossRef]

27. Ulses, C.; Estournel, C.; Durrieu de Madron, X.; Palanques, A. Suspended sediment transport in the Gulf of Lions (NW Mediterranean): Impact of extreme storms and floods. Cont. Shelf Res. 2008, 28, 2048-2070. [CrossRef]

28. Fard, I.K.P. Modélisation des Échanges Dissous Entre L'estuaire de la Loire et les Baies Côtières Adjacentes. Ph.D. Thesis, University of Bordeaux, Bordeaux, France, 2015.

29. Lurton, X. An Introduction to Underwater Acoustics: Principles and Applications; Springer: Berlin, Germany, 2002.

30. Tessier, C.; Le Hir, P.; Lurton, X.; Castaing, P. Estimation de la matière en suspension à partir de l'intensité rétrodiffusée des courantomètres acoustiques à effet Doppler (ADCP). C. R. Geosci. 2008, 340, 57-67. (In French) [CrossRef]

31. Lazure, P.; Dumas, F. An external-internal mode coupling for a 3D hydrodynamical model for applications at regional scale (MARS). Adv. Water Resour. 2008, 31, 233-250. [CrossRef]

32. Song, Y.; Haidvogel, D. A semi-implicit ocean circulation model using a generalized topography-following coordinate system. J. Comput. Phys. 1994, 115, 228-244. [CrossRef]

33. Rodi, W. Turbulence Models and Their Application in Hydraulics, 3rd ed.; IAHR Monograph: Delft, The Netherlands, 1993.

34. Ferry, N.; Parent, L.; Garric, G.; Barnier, B.; Jourdain, N.C. Mercator global Eddy permitting ocean reanalysis GLORYS1V1: Description and results. Mercator-Ocean Q. Newsl. 2010, 36, 15-27.

35. Boudière, E.; Maisondieu, C.; Ardhuin, F.; Accensi, M.; Pineau-Guillou, L.; Lepesqueur, J. A suitable metocean hindcast database for the design of Marine energy converters. Int. J. Mar. Energy 2013, 3-4, e40-e52. [CrossRef]

36. Déqué, M.; Dreveton, C.; Braun, A.; Cariolle, D. The ARPEGE/IFS atmosphere model: A contribution to the French community climate modelling. Clim. Dyn. 1994, 10, 249-266. [CrossRef]

37. Lyard, F.; Lefèvre, F.; Letellier, T.; Francis, O. Modelling the global ocean tides: Modern insights from FES2004. Ocean Dyn. 2006, 56, 394-415. [CrossRef]

38. Jonsson, I.G. Wave boundary layers and friction factors. In Proceedings of the 10th International Conference on Coastal Engineering, Tokyo, Japan, September 1966; American Society of Civil Engineers: New York, NY, USA, 1966; pp. 127-148.

39. Soulsby, R.L.; Hamm, L.; Klopman, G.; Myrhaug, D.; Simons, R.R.; Thomas, G.P. Wave-current interaction within and outside the bottom boundary layer. Coast. Eng. 1993, 21, 41-69. [CrossRef]

40. Soulsby, R. Dynamics of Marine Sands: A Manual for Practical Applications; Thomas Telford: London, UK, 1997.

41. Grasso, F.; Le Hir, P.; Bassoullet, P. Numerical modelling of mixed-sediment consolidation. Ocean Dyn. 2015, 65, 607-616. [CrossRef]

42. Van Leussen, W. Estuarine Macroflocs and Their Role in Fine-Grained Sediment Transport. Ph.D. Thesis, University of Utrecht, Utrecht, The Netherlands, 1994.

43. Tessier, C.; Le Hir, P.; Dumas, F.; Jourdin, F. Modélisation des turbidités en Bretagne sud et validation par des mesures in situ. Eur. J. Environ. Civ. Eng. 2008, 12, 179-190. [CrossRef]

44. Verney, R.; Gangloff, A.; Chapalain, M.; Le Berre, D.; Jacquet, M. Floc features in estuaries and coastal seas. In Proceedings of the 5th Particles in Europe Conference, Budapest, Hungary, 3-5 October 2016.

45. Dyer, K.R. Coastal and Estuarine Sediment Dynamics; John Wiley \& Sons: New York, NY, USA, 1986.

46. Mengual, B. Variabilité Spatio-Temporelle des Flux Sédimentaires Dans le Golfe de Gascogne: Contributions Relatives des Forçages Climatiques et des Activités De Chalutage. Ph.D. Thesis, University of Western Brittany, Brest, France, 2016. 
47. Bouysse, P.; Lesueur, P.; Klingebiel, A. Carte Des Sédiments Superficiels du Plateau Continental du Golfe de Gascogne: Partie Septentrionale au 1/500 000. Co-Éditée par le BRGM Et l'IFREMER, 1986. Available online: http:/ / sextant.ifremer.fr/record/ea0b61b0-71c6-11dc-b1e4-000086f6a62e/ (accessed on 21 July 2017).

48. Mengual, B.; Cayocca, F.; Le Hir, P.; Draye, R.; Laffargue, P.; Vincent, B.; Garlan, T. Influence of bottom trawling on sediment resuspension in the "Grande-Vasière" area (Bay of Biscay, France). Ocean Dyn. 2016, 66, 1181-1207. [CrossRef]

49. Van Rijn, L.C. Unified view of sediment transport by currents and waves. II: Suspended transport. J. Hydraul. Eng. 2007, 133, 668-689. [CrossRef]

50. Van Rijn, L.C. Sediment transport, part II: Suspended load transport. J. Hydraul. Eng. 1984, 110, $1613-1641$. [CrossRef]

51. Engelund, F.; Hansen, E. A Monograph on Sediment Transport in Alluvial Streams; Teknish Forlag, Technical Press: Copenhagen, Denmark, 1967.

52. Yang, C.T. Incipient motion and sediment transport. J. Hydraul. Div. 1973, 99, 1679-1704.

53. Dufois, F.; Le Hir, P. Formulating Fine to Medium Sand Erosion for Suspended Sediment Transport Models. J. Mar. Sci. Eng. 2015, 3, 906-934. [CrossRef]

54. Winterwerp, J.C. Flow-Induced Erosion of Cohesive Beds; A Literature Survey. Rijkswaterstaat-Delft Hydraulics, Cohesive Sediments Report 25, February 1989. Available online: http:/ / publicaties.minienm.nl/ download-bijlage/45703/164198.pdf (accessed on 21 July 2017).

55. Tessier, C. Caractérisation et Dynamique des Turbidités en Zone Côtière: L'exemple de la Région Marine Bretagne Sud. Ph.D. Thesis, University of Bordeaux 1, Bordeaux, France, 2006.

56. Raudkivi, A.J. Loose Boundary Hydraulics, 3rd ed.; Pergamon Press: Oxford, UK, 1990.

57. Bassoullet, P.; Le Hir, P.; Gouleau, D.; Robert, S. Sediment transport over an intertidal mudflat: Field investigations and estimation of fluxes within the "Baie de Marennes-Oléron" (France). Cont. Shelf Res. 2000, 20, 1635-1653. [CrossRef]

58. Winterwerp, J.C.; Van Kesteren, W.G.M. Introduction to the Physics of Cohesive Sediment Dynamics in the Marine Environment; Developments in Sedimentology; Elsevier: Amsterdam, The Netherlands, 2004.

(C) 2017 by the authors. Licensee MDPI, Basel, Switzerland. This article is an open access article distributed under the terms and conditions of the Creative Commons Attribution (CC BY) license (http:/ / creativecommons.org/licenses/by/4.0/). 